\title{
Revised Badenian (middle Miocene) depositional systems of the Austrian Vienna Basin based on a new sequence stratigraphic framework
}

\author{
Wolfgang SIEDL ${ }^{1 *}$, Philipp STRAUSS', Reinhard F. SACHSENHOFER², Mathias HARZHAUSER ${ }^{3}$, Thomas KUFFNER' \& Matthias \\ KRANNER ${ }^{3}$ \\ 1) OMV Exploration \& Production GmbH, Trabrennstraße 6-8, 1020 Vienna, Austria; wolfgang.siedl@omv.com, philipp.strauss@omv.com, thomas.kuffner@ \\ omv.com \\ 2) Department of Applied Geosciences and Geophysics, Franz Josef-Straße 8, 8700 Leoben, Austria; reinhard.sachsenhofer@unileoben.ac.at \\ 3) Geological-Palaeontological Department, Natural History Museum Vienna, Burgring 7, 1010 Vienna, Austria; mathias.harzhauser@nhm-wien.ac.at, \\ matthias.kranner@nhm-wien.ac.at \\ *) Corresponding author: wolfgang.siedl@omv.com
}

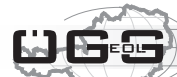

KEYWORDS Vienna Basin, Austria, Miocene, Badenian, depositional system, sequence stratigraphy

\begin{abstract}
This paper presents a revised sequence stratigraphy for the lower, middle and upper Badenian depositional systems of the Austrian Vienna Basin based on the integration of 3D seismic surveys and well data. The study area in the central and northern part of the Austrian Vienna Basin is covered with 3D seismic data. According to a new sequence stratigraphic framework established in the southern part of the Vienna Basin, the Badenian is subdivided into three $3^{\text {rd }}$ order depositional sequences. For each sequence, paleogeographic maps are created, representing coeval depositional systems within a chronostratigraphic interval. Lower Badenian sediments of the $1^{\text {st }}$ sequence (Ba1) represent fillings of the pre-Badenian sub-basins with a major change of sediment transport direction. The early stage of the $1^{\text {st }}$ sequence is dominated by subaerial braided river deposits which use two pronounced canyon systems (Mistelbach Canyon and Reinthal Canyon) on the northwestern margin of the Vienna Basin as a bypass zone towards the marine depositional system of the North Alpine-Carpathian Foredeep. The late stage of the $1^{\text {st }}$ sequence reflects the change from subaerial to marine depositional environments with main sediment influx from the west, creating two major eastwards prograding delta systems (Zistersdorf Delta and Mühlberg Delta). Depositional systems of the middle Badenian $2^{\text {nd }}$ sequence ( $\mathrm{Ba} 2$ ) reflect the interplay between ongoing extensional fault tectonics and major sea-level changes. Lower Badenian paleo-highs in the northern part are drowned during the $3^{\text {rd }}$ sequence (Ba3), thus the Mühlberg Delta and the Zistersdorf Delta merge into one delta system. During the Ba3 the drowning of the Spannberg Ridge initiates a clockwise rotation of the Zistersdorf Delta. Thus, the former Zistersdorf Delta transforms into the Matzen Delta covering the Spannberg Ridge. Together with the Mühlberg Delta, they represent the last full marine depositional system of the eastward prograding paleo-Danube Delta in the Austrian Vienna Basin.
\end{abstract}

\section{Introduction}

The Vienna Basin is a major fault controlled basin at the transition zone between the Eastern Alps (Central Alps, Northern Calcareous Alps) and the Western Carpathians (Figs. 1, 2). Based on its rhombohedral shape (Fig. 1) and its position on top of the Alpine-Carpathian nappes, Royden (1985) interpreted the Vienna Basin as a pull-apart basin. Seismic interpretation by OMV AG Exploration (Austria) showed that the Vienna Basin is a polyphase basin with early Miocene piggy back and pull-apart phases and a middle to late Miocene east-west extensional phase with the formation of large half-graben systems (Hinsch et al., 2005; Beidinger and Decker, 2016). Only in recent times certain parts in the vicinity of the Vienna Basin show again a pull-apart kinematic (Salcher et al., 2012).

During Miocene time the Vienna Basin area formed part of the Central Paratethys (e.g. Rögl et al., 2002). Consequently, Central Paratethys stratigraphy (e.g. Piller et al., 2007; Hilgen et al., 2012) is used in this paper (Fig. 3). This paper focuses on Badenian (middle Miocene) depositional systems. The base of the Badenian corresponds to the sea-level lowstand at the Bur 5/Lan 1 sequence boundary of Hardenbol et al. (1998) defining the base of the Langhian, whereas the top of the Badenian is related to the Ser 3 lowstand within the Serravallian (Piller et al., 2007; Hilgen et al., 2012). Traditionally the Badenian is subdivided into lower, middle and upper Badenian units (e.g. Rögl et al., 2008 cum lit.), which can be correlated to the sea-level cycles TB 2.3 to TB 2.5 of Haq et al. (1988) and Piller et al. (2007). The top of the lower Badenian is formed by a major erosional unconformity correlated with the Lan 2/Ser 1 sequence boundary of Hardenbol et al. (1998), while the top of the middle Badenian corresponds to the Ser 2 lowstand and the Langhian/Serravallian boundary (Piller et al. 2007).

The Vienna Basin hosts one of the largest hydrocarbon provinces in Central Europe (Arzmüller et al., 2006; Boote et al., 2018; Rupprecht et al., 2019). Hydrocarbon production commenced about 90 years ago and the giant Matzen field in the centre of the Vienna Basin produced more than 550 million bbl oil and 1.2 TCF gas over the last 70 years (Arzmüller et al., 2006; Boote et al., 2018). Sixteen 


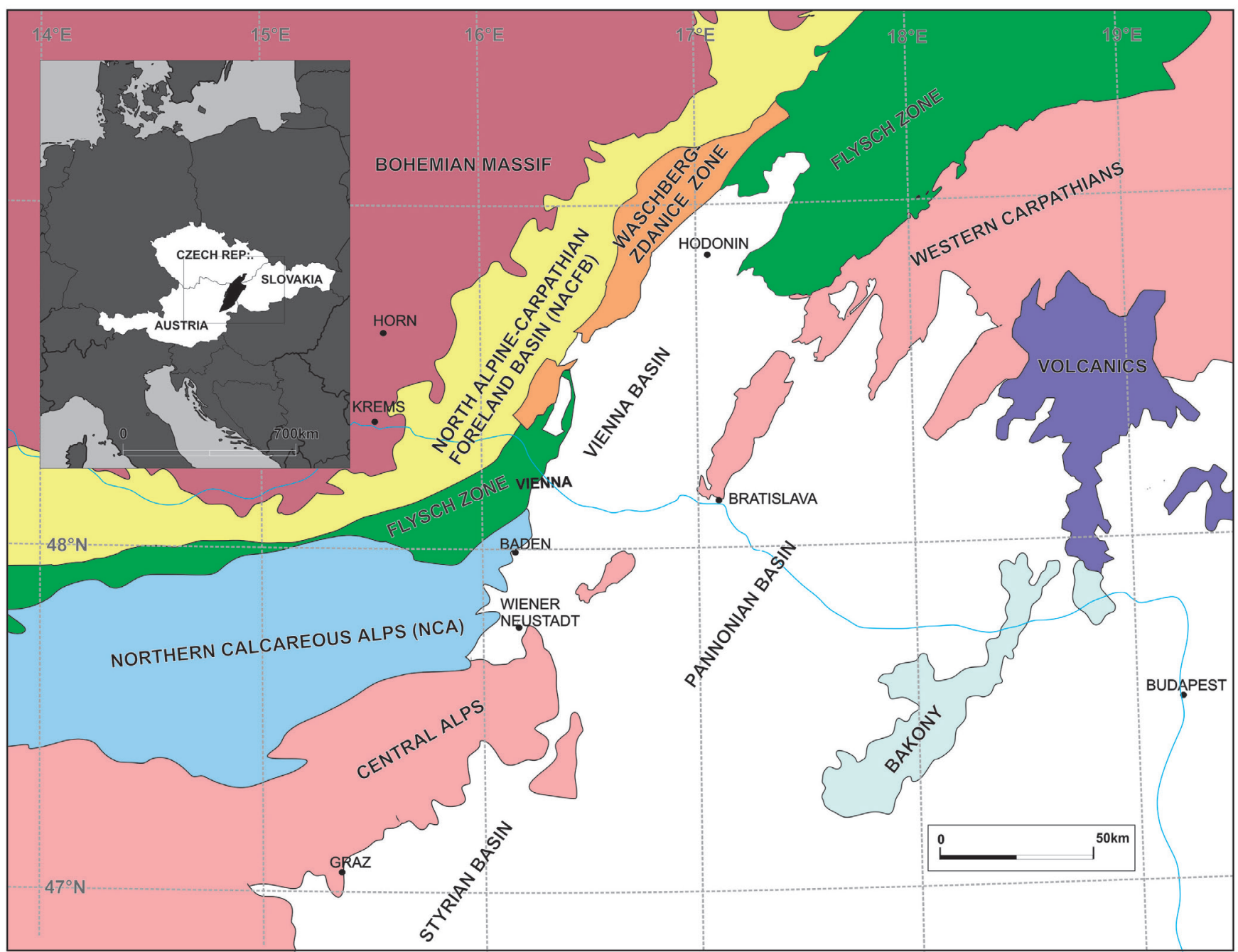

Figure 1: Regional geology (modified after Schnabel et al., 2002; Beidinger and Decker, 2016). The map comprises from northwest to southeast Paleozoic crystalline units of the Bohemian Massif (magenta), Miocene sediments of the North Alpine-Carpathian Foreland Basin (NAFCB, yellow), Jurassic to lower Miocene deposits of the Waschberg-Ždánice Zone (orange), Cretaceous to Paleogene Flysch units (green), Triassic to Cretaceous units of the Northern Calcareous Alps (NCA, light blue), Paleozoic units of the Central Alps (pink), Miocene to Quaternary sediments of the Vienna Basin, Styrian Basin and Pannonian Basin (white), Paleozoic to Cenozoic units of Western Carpathians (pink, light blue) and Neogene to Quaternary volcanics (dark blue)

Badenian reservoir horizons are present in the Matzen field (labelled from top to bottom as 1.TH to 16.TH; Arzmüller et al., 2006). The most important horizon is a middle Badenian transgressive sand (16.TH or Matzen Sand). Other prominent reservoir horizons include the upper Badenian 9.TH and the 8.TH.

Oil and gas production in the Vienna Basin peaked in 1955 and the mid-1960s, respectively (e.g. Hamilton et al., 2000). Since then, adding new reserves to compensate hydrocarbon production decline became a major challenge, which required new geological interpretation techniques and methodologies. Starting in the late 1980s, sequence stratigraphic concepts were introduced in the Vienna Basin. These studies, based mainly on well data (well logs, well cores), were focused on producing fields such as the Matzen or Mühlberg fields (Kreutzer, 1986, 1992, 1993; Kreutzer and Hlavay, 1990; Sauer et al., 1992; Weissenbäck, 1996; Fuchs et al., 2006). Wells, drilled between producing fields, were used for cross correlation to establish a regional sequence stratigraphic framework (Kreutzer, 1986). However, these models suffered from the fact that $2 \mathrm{D}$ seismic data were hardly used, mainly because of limited quality.

The acquisition of 3D seismic data over the last two decades in the central and northern parts of the Austrian Vienna Basin enabled the application of new techniques, like seismic facies interpretation. In the present paper, this technique is used as input for comprehensive sequence stratigraphic models, which are based on the sequence stratigraphic framework of the Vienna Basin established by Strauss et al. (2006).

Paleogeographic maps for the Miocene of the Vienna Basin have been published previously (e.g. Jiříček and Seifert, 1990; Sauer et al., 1992; Kováč et al., 2004; Wessely, 2006). The main aim of this paper is to use new sequence stratigraphic models to prepare a set of paleogeographic maps for different Badenian time slices in the central Vienna Basin with so far unreached spatial and temporal resolution. 


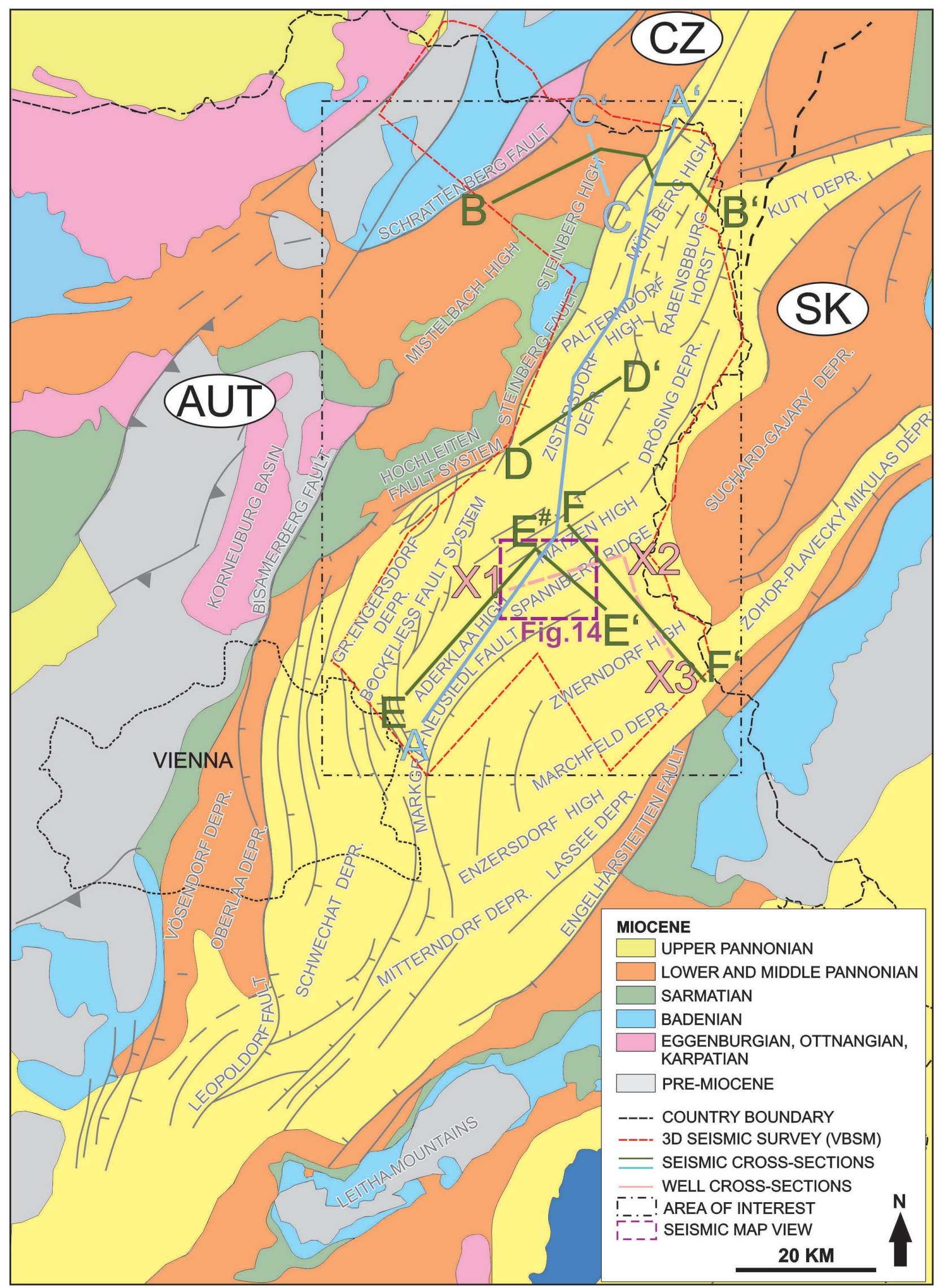

Figure 2: Geological surface map of the central and northern part of the Vienna Basin and the main fault systems (modified after Wessely, 2006). The red polyline outlines the available 3D seismic survey (VBSM, Vienna Basin Super Merge seismic survey); the dashed polyline represents the Austrian border; green and blue polylines represent seismic cross-sections, the pink polyline represents a well cross-section and the magenta rectangle shows the position of a seismic map in the Matzen field (Fig. 14). 


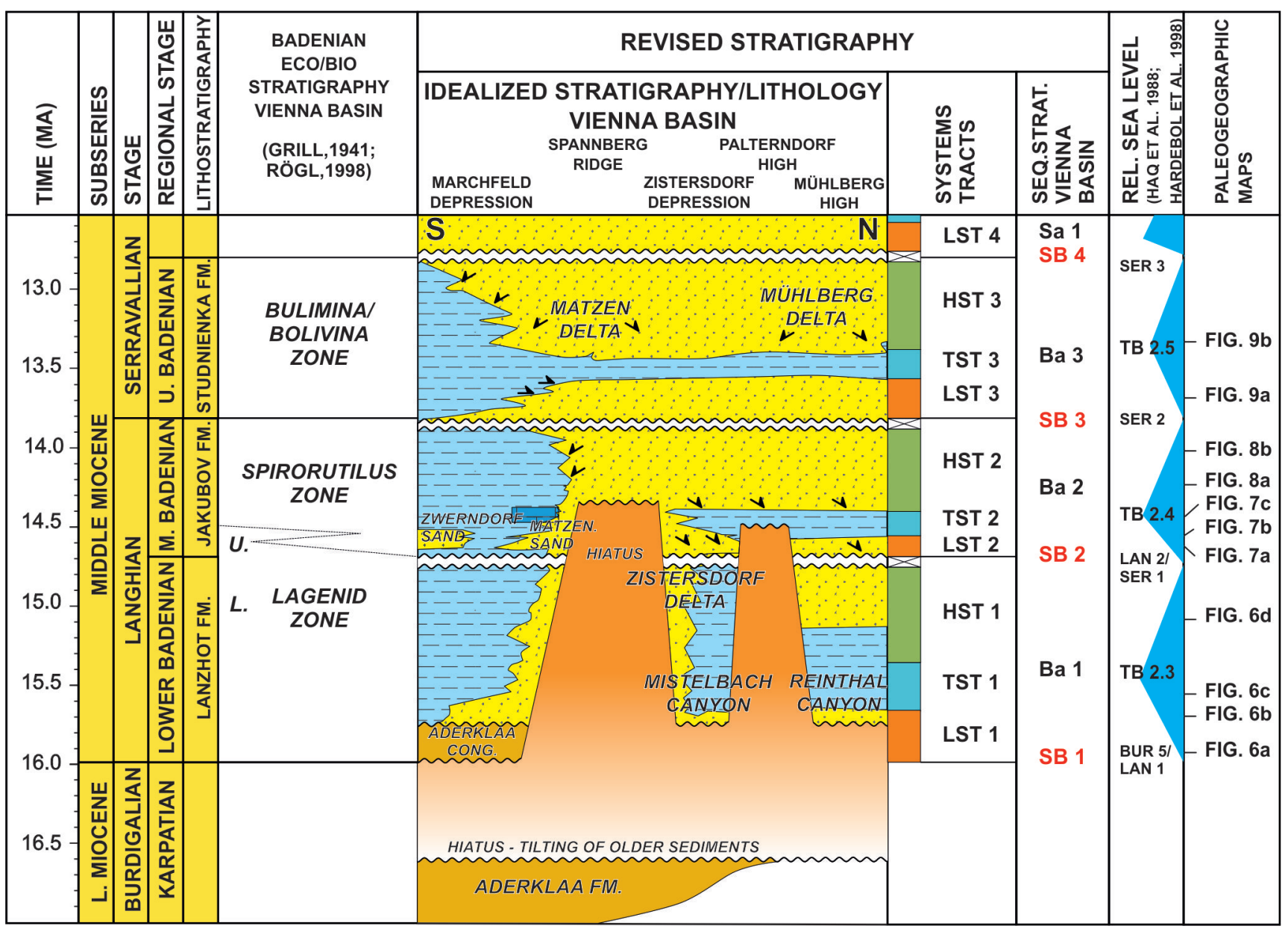

Figure 3: Chronostratigraphic chart, revised and updated after Kreutzer (1986) and Strauss et al. (2006). In contrast to previous stratigraphic models, where the Vienna Basin is assumed as a single accommodation, the new model distinguishes three early Badenian sub-basins: a southern basin (Marchfeld Depression), a central basin (Zistersdorf Depression) and a northern basin (Mühlberg High). Each of these basins creates separate depositional systems. These basins are merged together during middle Badenian time, forming a single genetically related depositional system in the middle to upper Badenian. Systems tracts are classified as lowstand systems tract (LST), transgressive systems tract (TST) and highstand systems tract (HST). Badenian sequences are abbreviated as Ba1, Ba2 and Ba3 and the Sarmatian sequence is abbreviated as Sa1. All sequences are $3^{\text {rd }}$ order. Sequence boundaries are abbreviated with SB.

\section{Geological Setting}

The position of the Vienna Basin in the context of the regional Alpine-Carpathian tectonic regime is shown in the Fig. 1. Northward movement of the Alpine and Carpathian nappes caused north to northwest thrusting (e.g. thinskinned Waschberg-Ždánice zone) with a contemporaneous depocenter shift from the North Alpine Foreland Basin into the Carpathian Foredeep (Meulenkamp et al., 1996; Picha et al., 2006).

A geological overview map of the Vienna Basin is provided in Fig. 2 (Wessely, 2006). It shows that Pannonian (upper Miocene) sediments are widespread in the central Vienna Basin. Therefore, outcrops with Badenian successions are limited mainly to the basin margins. Major extensional fault systems define the western margin of the central Vienna Basin (Fig. 2). These include the Steinberg Fault, the Hochleiten Fault system, the Bockfliess Fault system and the Markgrafneusiedl Fault. Regional highs in the basin (e.g. Mühlberg High, Rabensburg Horst, Matzen High, Zwerndorf High and Aderklaa High) are separated by depressions (e.g. Zistersdorf Depression, Drösing Depression, Marchfeld Depression, Gr. Engersdorf
Depression; Fig. 2). The northern and eastern boundary of the zone of investigation is defined by the Austrian border (black dashed polyline in Fig. 2).

Lowermost Badenian strike-slip fault systems (Wagreich and Schmid, 2002) gradually change to middle Badenian extensional fault systems. Contemporaneous to the change of the tectonic regime, sediment transport directions changes too. Upper Karpatian to lower Badenian sediment influx is mainly from the south or north, whereas west to east sediment transport prevails during the middle Badenian, mainly related to the eastward prograding delta system of the paleo-Danube (Sauer et al., 1992). Based on well log data and limited 2D seismic data, a middle Badenian depositional map is constructed by Jiříček and Seifert (1990). It indicated the presence of two delta branches of the paleo-Danube, a northern one heading towards the Czech Republic and a southern one heading towards the Slovak Republic.

\section{Database}

The Vienna Basin in Austria was intensively explored and developed by the oil industry, drilling over 3800 wells. 

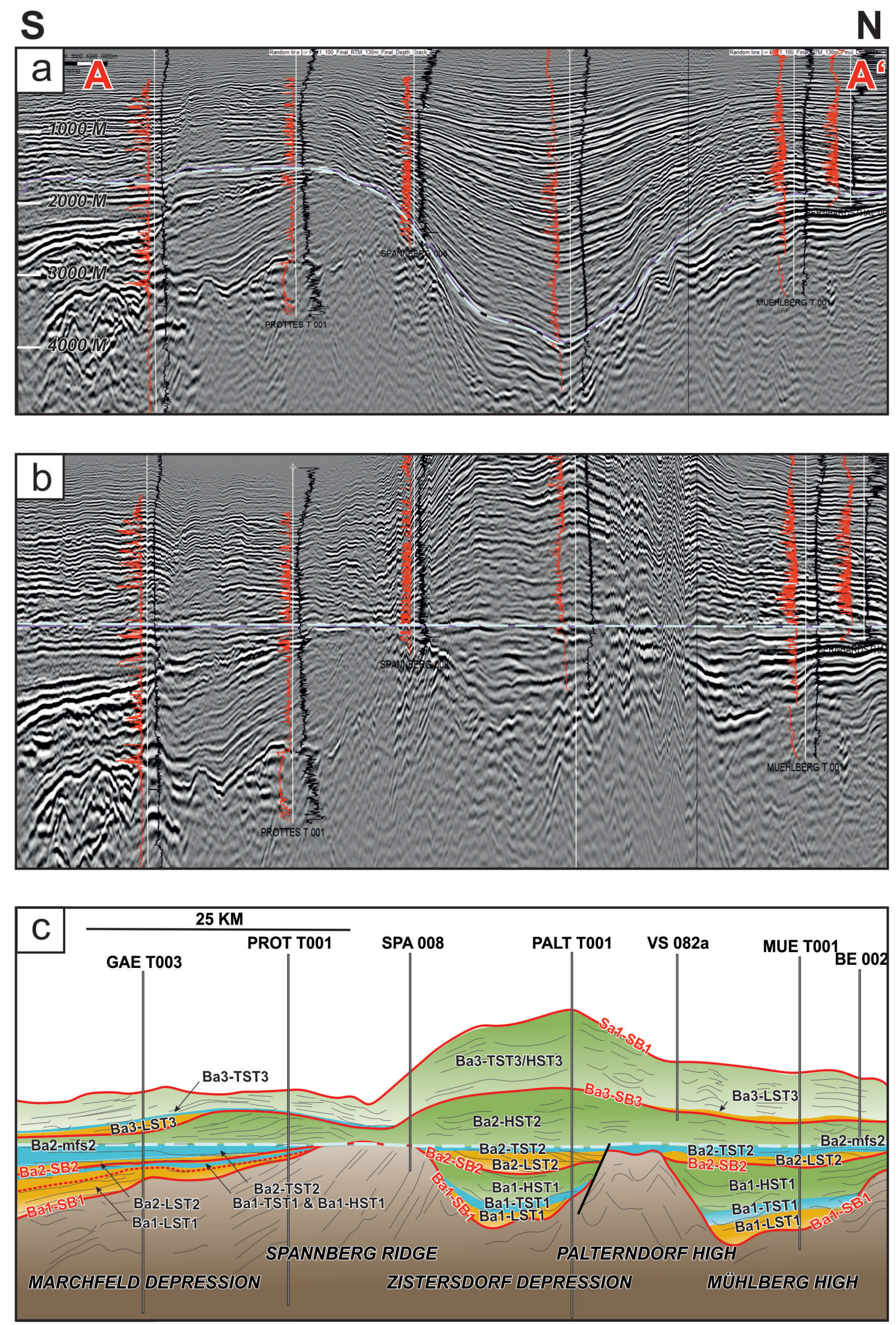

Figure 4: South to north seismic profile through the Vienna Basin. (a) Original seismic profile with spontaneous (red) and resistivity (black) logs from key wells and the reference horizon Ba2-mfs2 (dashed line). (b) Seismic profile flattened on the reference horizon Ba2-mfs2 (blue dashed line). (c) Systems tracts of the Badenian flattened on the reference horizon Ba2-mfs2; orange shaded zones represent lowstand systems tracts, blue shaded zones represent transgressive systems tracts, green shaded zones represent highstand systems tracts and red lines represent sequence boundaries. The dashed red line marks the boundary between the early and late Ba1-LST1 lowstand systems tracts. Obvious are the separated sub-basins in the Zistersdorf Depression and Mühlberg High, filled by lower Badenian sediments. For each systems tract at least one paleogeographic map is prepared. 


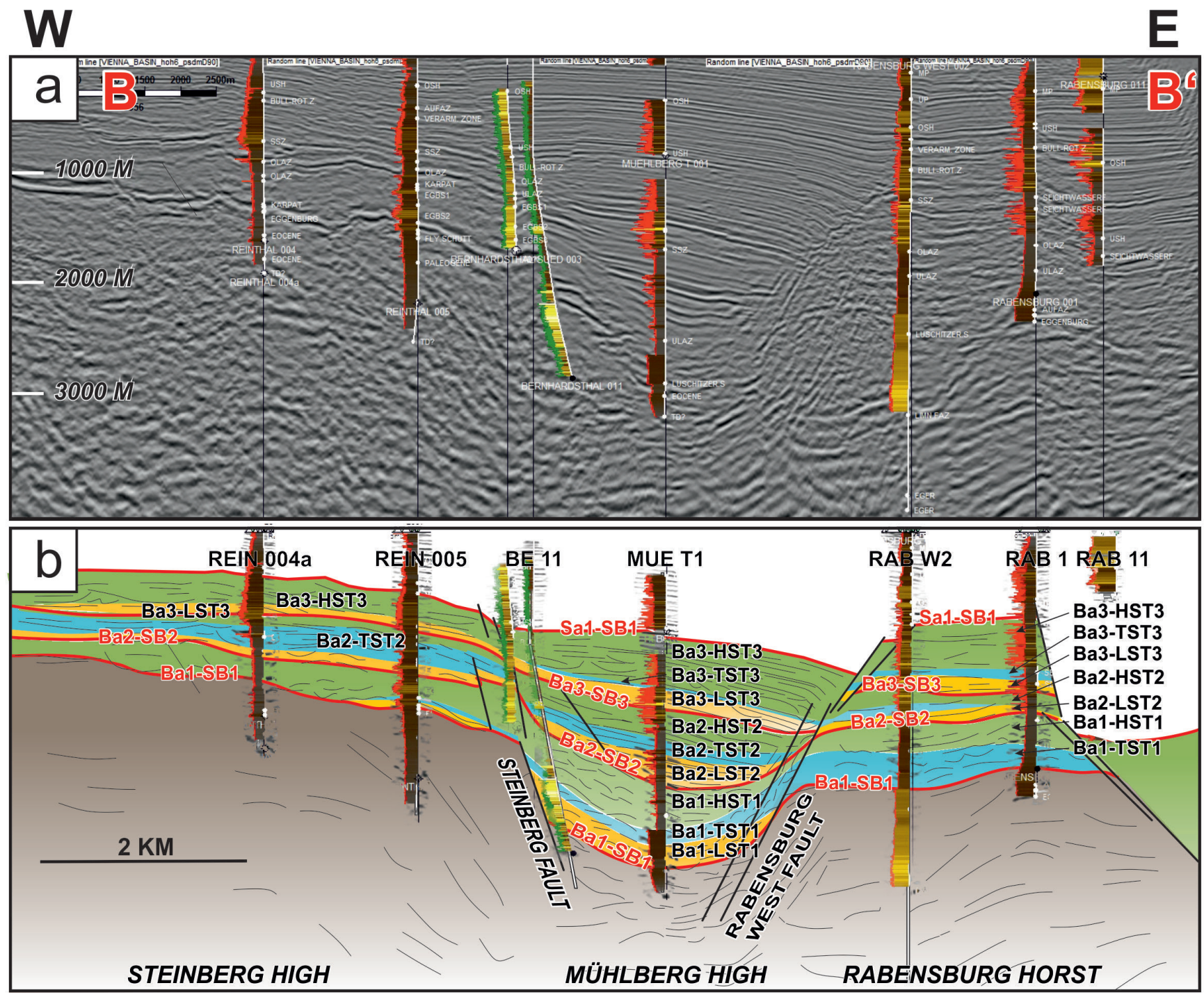

Figure 5: (a) West to east seismic profile in the northern part of the Vienna Basin with spontaneous (red) and gamma ray (green) logs of key wells. Low well log values are colored in yellow and high well log values are colored in brown. (b) Systems tracts of the Badenian; orange shaded zones represent lowstand systems tracts, blue shaded zones represent transgressive systems tracts, green shaded zones represent highstand systems tracts and red lines represent sequence boundaries.

Most wells focus on Sarmatian and Badenian (middle Miocene) siliciclastic systems, which are the principal hydrocarbon bearing zones. In addition, wells were drilled targeting underlying Karpatian and Ottnangian or even deeper Mesozoic units. Ultra-deep wells like ZI UET 001, positioned in the centre of the Zistersdorf Depression drilled to the depth of $8553 \mathrm{~m}$, tried to reach the source rock in the basement of the Vienna Basin.

Out of this huge data set, 350 wells with proper well log data were preselected. As the data volume was still too large, an additional selection focused on wells with detailed sedimentological and sequence stratigraphic reports (e.g., Kuffner and Sauer, 2006; Kuffner, 2010, $2011,2012,2016,2017)$. The final selection yielded about 85 wells representing different depositional systems. These wells were used to construct well cross-sections. Several well cross-sections were prepared across the Vienna Basin in order to combine wells, which are representative for a specific area and to define local lithostratigraphic and sequence stratigraphic relationships. Finally, well cross-sections were selected which are along or perpendicular to sediment transport directions. Seismic data of several seismic vintages (19942013) were merged to an approximately $1800 \mathrm{~km}^{2}$ seismic survey called Vienna Basin Super Merge (VBSM). The extension of the VBSM is shown in Fig. 2. Seismic processing was performed by OMV in-house between May 2012 and February 2014 to create a post stack timeand-depth migrated seismic survey.

\section{Terminology}

The nomenclature of the sequence stratigraphy in this paper is based on the terminology of Posamentier and Vail (1988), Van Wagoner et al. (1990), Emery and Myers (1996), Catuneanu et al. $(2009,2011)$ and Catuneanu (2017). The sequence stratigraphic model based on Posamentier and Vail (1988) is preferred, because of the good visibility of a sea-level fall at the end of the highstand systems tract 

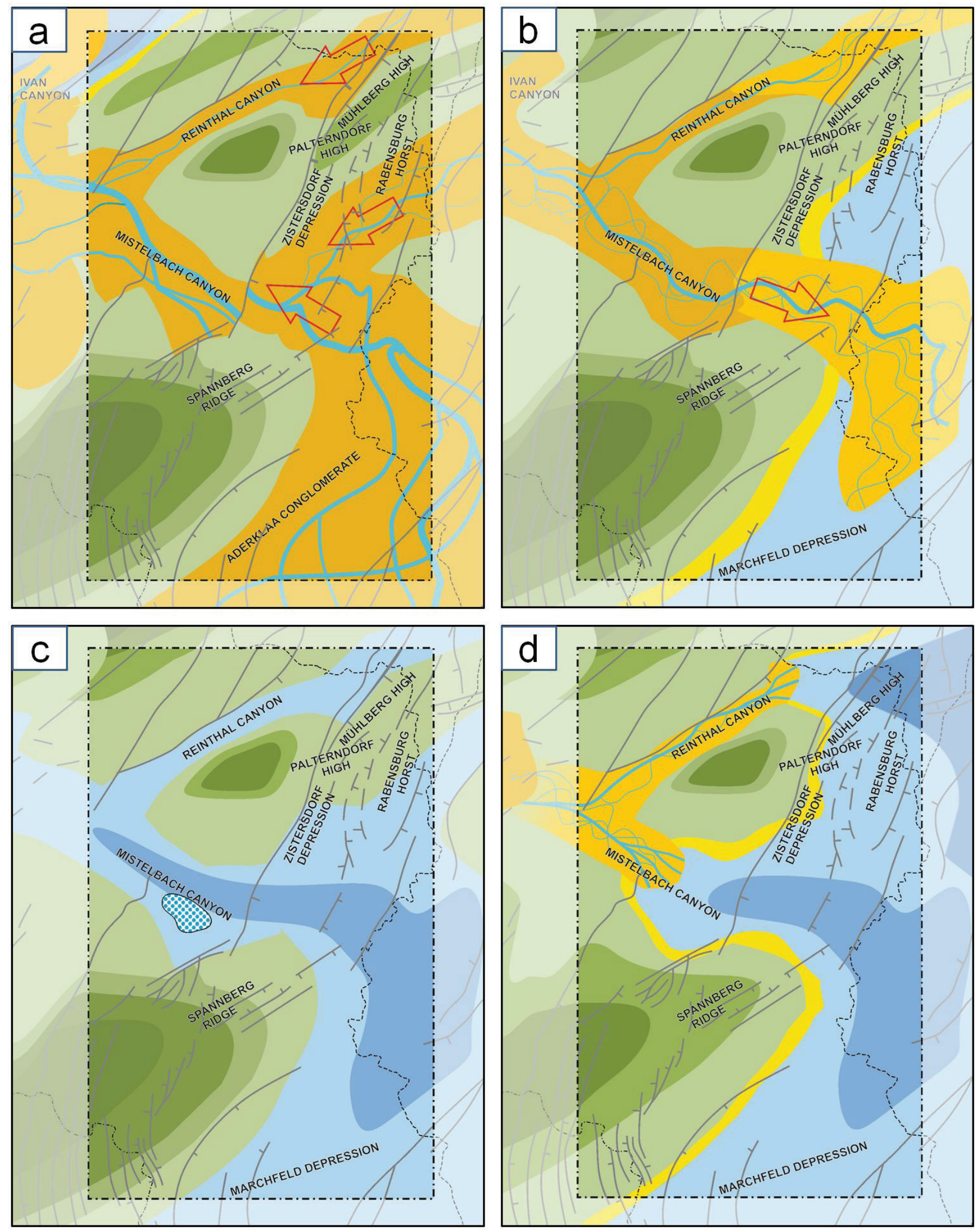

Figure 6: Paleogeographic maps of the Ba1 systems tract (a) early Ba1-LST1 (b) late Ba1-LST1, (c) Ba1-TST1, (d) Ba1-HST1. The legend is provided in Figure 7. 

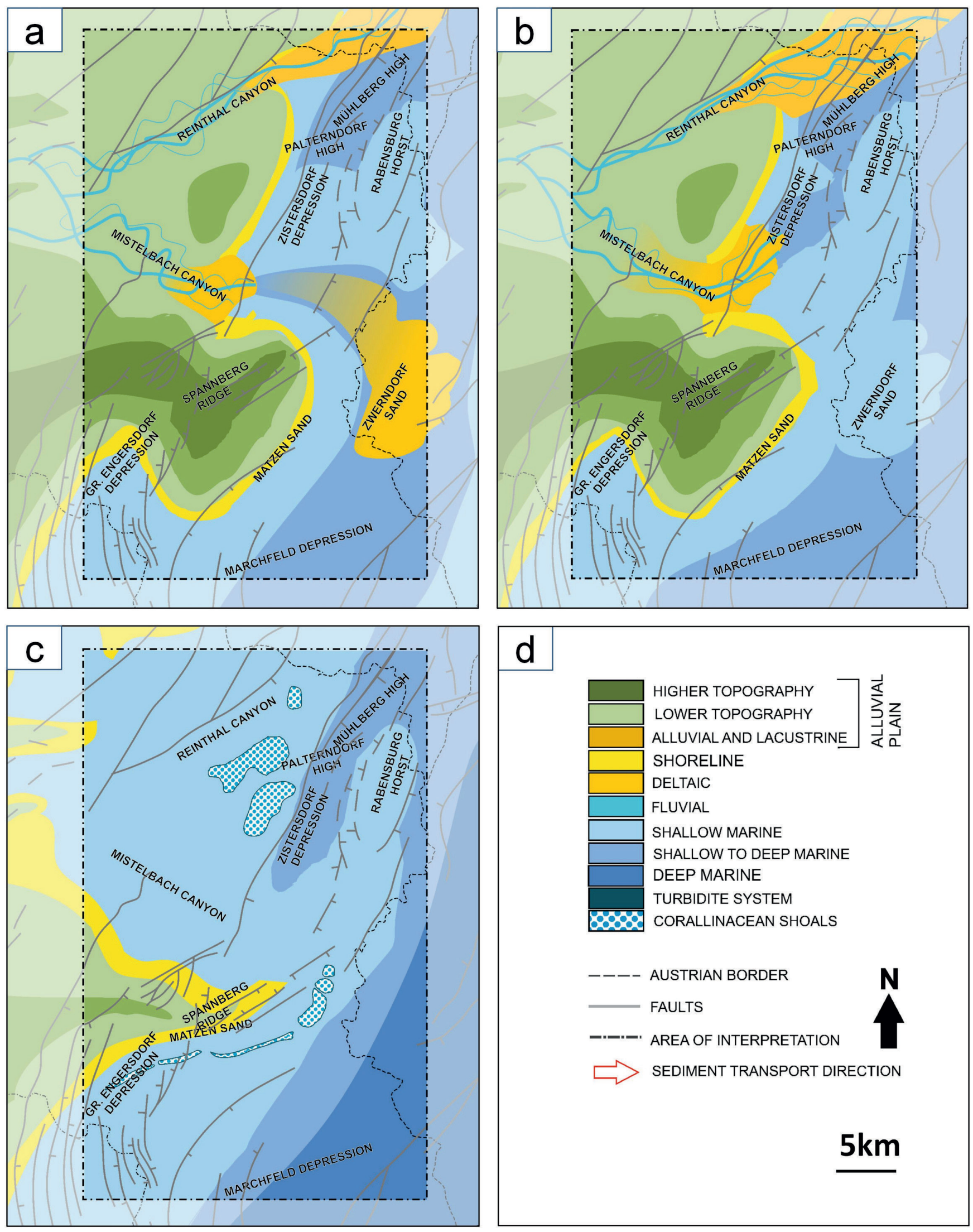

d
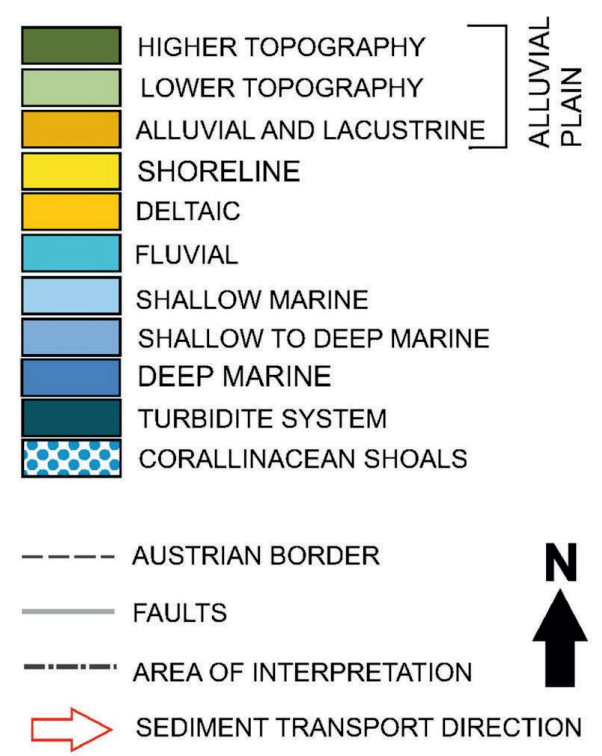

$5 \mathrm{~km}$

Figure 7: Paleogeographic maps of the Ba2 systems tracts (a) early Ba2-LST2, (b) late Ba2-LST2, (c) Ba2-TST2, (d) legend for Figures 6 to 9. 

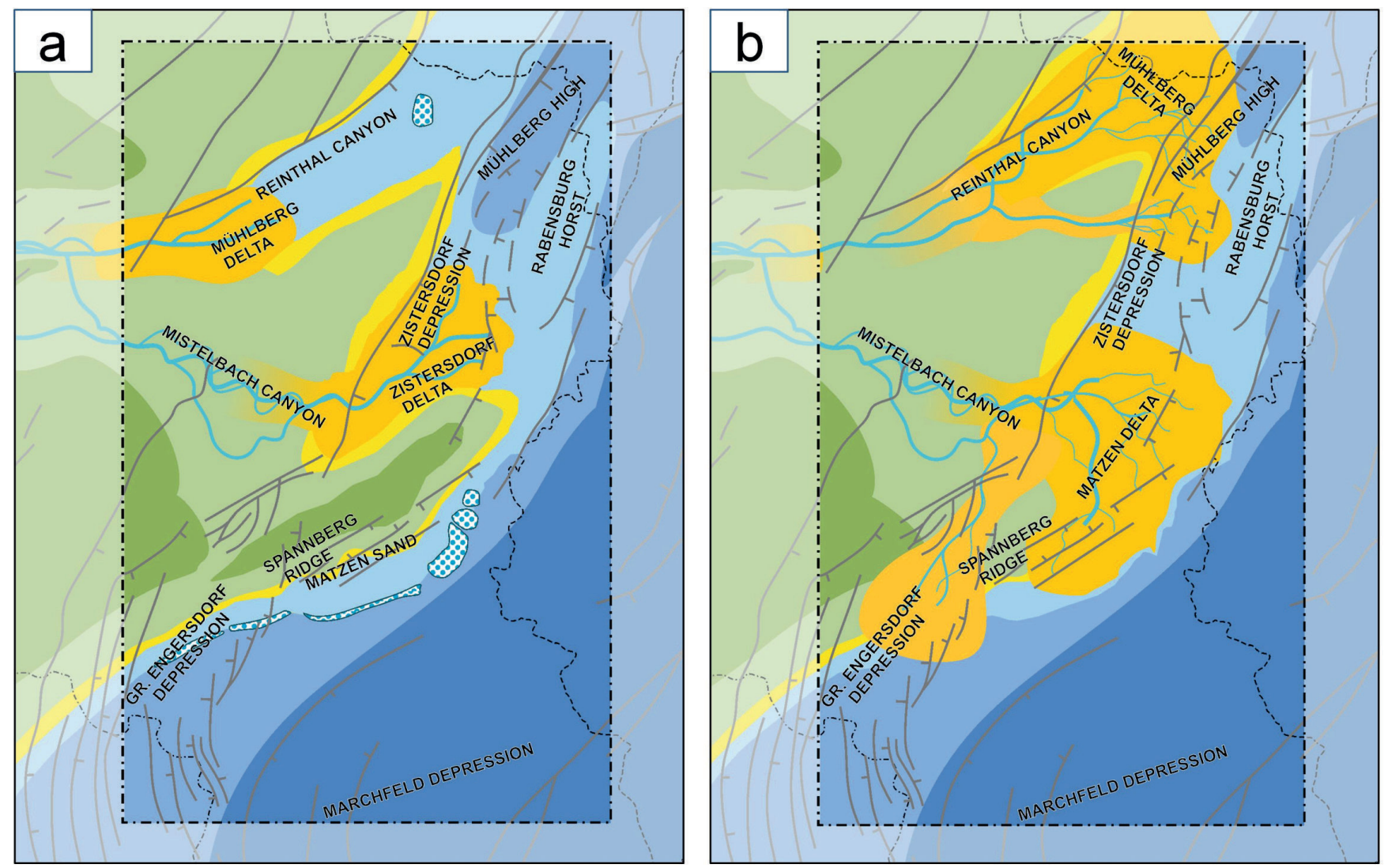

Figure 8: Paleogeographic maps of the Ba2 systems tracts (a) early Ba2-HST2, (b) late Ba2-HST2. Legend is provided in Figure 7.

on 3D seismic data. Therefore, the sequence boundary (SB) is set between the highstand systems tract (HST) and the following early lowstand systems tract (LST). The end of the transgressive systems tract (TST) is marked by the maximum flooding surface ( $\mathrm{mfs}$ ). Each of the Badenian $3^{\text {rd }}$ order sequences are termed Ba with an order number, where the lowest order number is the oldest sequence. All sequences are $3^{\text {rd }}$ order. Sequence names and systems tracts are combined to specify distinctive Badenian systems tracts; for instance Ba1-LST1 means the first $3^{\text {rd }}$ order lowstand systems tract of the Badenian stratigraphic sequence one (Tab.1).

\section{Badenian systems tracts and related depositional systems}

A revised stratigraphic chart of the Badenian succession in the northern and central sector of the Austrian Vienna Basin is created and is displayed in Fig. 3. It is based on chronostratigraphic and sequence stratigraphic charts of Kreutzer (1986) and Strauss et al. (2006) and considers biostratigraphic data revised recently by Harzhauser et al. (2017, 2018). An idealized lithostratigraphic south to north section of the studied area in the Vienna Basin is included together with Paratethys sea-level changes. Note that the new subdivision of the Badenian succession, based on Strauss et al. (2006), is slightly different to previous subdivisions, which are mainly based on eco-biostratigraphy and considered from base to top: Lower Lagenid Zone, Upper Lagenid Zone, Sandschaler Zone, and
Bulimina-Bolivina Zone (Grill, 1941, 1943). Modern literature changed the name of the Sandschaler Zone, characterised by the dominance of agglutinated foraminifers, to Spirorutilus Zone (Harzhauser et al., 2017).

The organization of Badenian systems tracts is displayed in a south to north trending seismic profile through the central Vienna Basin (A-A' in Fig. 2; Fig. 4) and a west to east seismic profile in the northern part of the Vienna Basin (B-B' in Fig. 2; Fig. 5). The profile in Fig. 4b, $c$ is flattened close to the Ba2-mfs2 maximum flooding surface and shows that the early Badenian basin configuration is characterized by two pronounced paleo-highs, the Spannberg Ridge and Palterndorf High. These paleo-highs separate sub-basins: the Marchfeld Depression, the Zistersdorf Depression and the Mühlberg High (Fig. 4). The Mühlberg High represents an inverted early Badenian sub-basin (Fig. 4b and 4c), which forms a present-day structural high (Fig. 4a). The sub-basin configuration is shown in Fig. 4, which is used as a reference for all investigated systems tracts discussed in the following.

For each systems tract of Badenian sequences representative depositional systems are constructed and summarized in paleogeographic maps (Figs. 6 to 9).

\subsection{Depositional system of the Ba1-LST1 upper Kar- patian/lower Badenian lowstand systems tract}

The Ba1-LST1 lowstand systems tract is marked as orange polygon in Figs. 4c, 5b, 10b and $11 \mathrm{~b}$. It is delimited at the base by the Ba1-SB1 sequence boundary. 

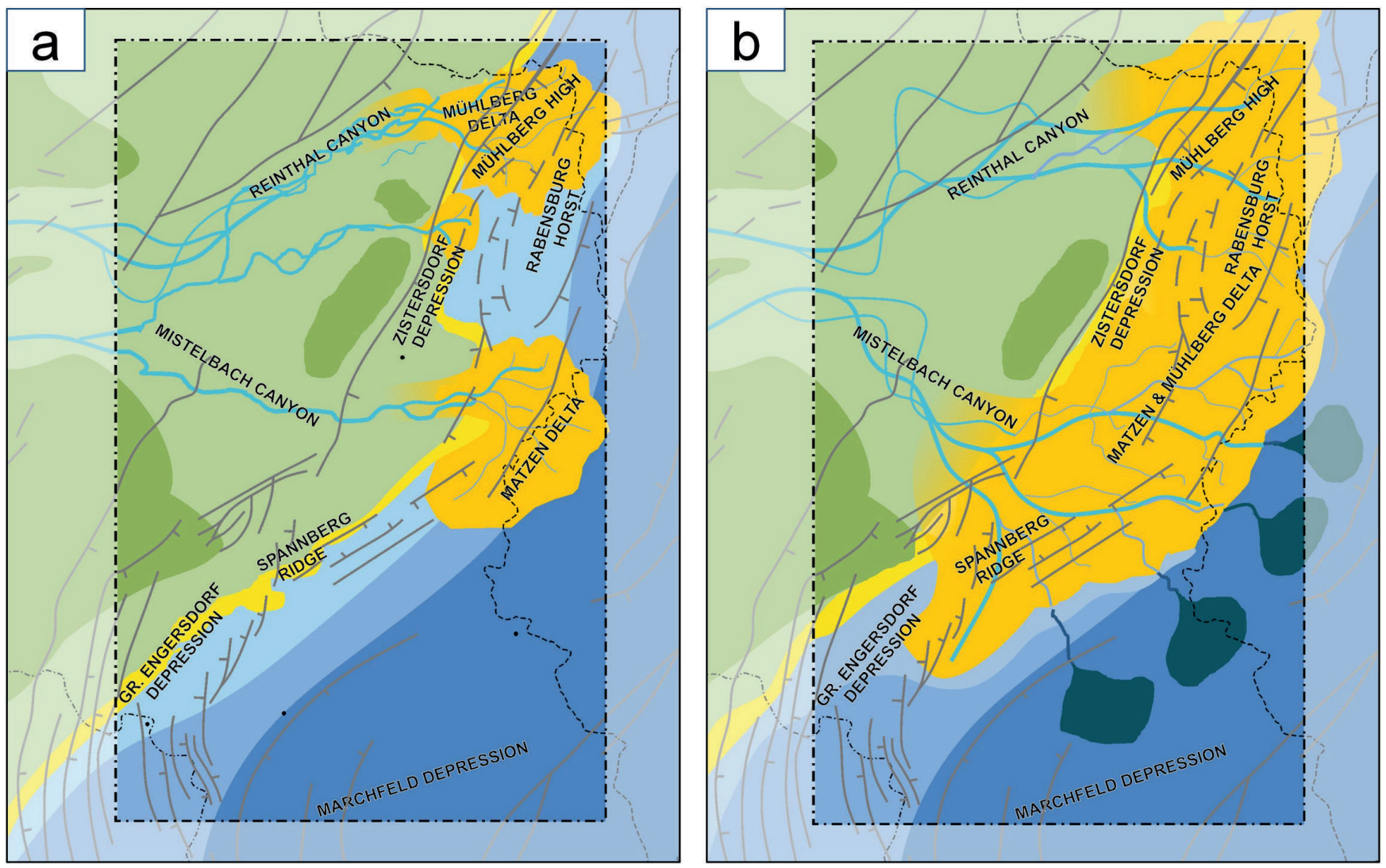

Figure 9: Paleogeographic maps of the Ba3 systems tracts (a) Ba3-LST3, (b) Ba3-TST3/HST3. Legend is provided in Figure 7.

Paleogeographic maps for the early and late Ba1-LST1 lowstand systems tracts are provided in Figs. 6a and 6b.

The precise age of the subaerial early Ba1-LST1 lowstand systems tract is poorly constrained. Generally, it is considered as the lowermost systems tract of the Badenian succession. Since direct biostratigraphic evidence is missing, a late Karpatian age cannot be excluded. The late Ba1-LST1 lowstand systems tract represents marine lower Badenian sediments, confirmed by biostratigraphy in the southern (Wessely, 2006) and in the northern parts of the study area (Harzhauser et al., 2017).
Seismic patterns indicate deep pre-Badenian erosion related to canyons or incised valleys, which are spread over the entire study area. Fig. 12 provides a seismic profile across the Reinthal Canyon in the northern part of the study area as an example. The Mistelbach Canyon (Harzhauser et al., 2017), another prominent canyon in the central study area, is connected to a large incised valley south of the Spannberg Ridge (Fig. 6a).

The early stage of the Ba1-LST1 systems tract is represented by the Aderklaa Conglomerate, which overlies Karpatian units discordantly in the south and southeast

\begin{tabular}{|c|c|c|c|}
\hline Stage & Sequence & $\begin{array}{c}\text { Systems Tract \& } \\
\text { Sequence Stratigraphic } \\
\text { Surfaces }\end{array}$ & Nomenclature \\
\hline \multirow{4}{*}{ upper Badenian } & \multirow{4}{*}{ Ba3 } & HST3 & $3^{\text {rd }}$ order highstand systems tract of the sequence Ba3 \\
\hline & & TST3 & $3^{\text {rd }}$ order transgressive systems tract of the sequence $\mathrm{Ba} 3$ \\
\hline & & LST3 & $3^{\text {rd }}$ order lowstand systems tract of the sequence Ba3 \\
\hline & & SB3 & sequence boundary of the sequence $\mathrm{Ba} 3$ \\
\hline \multirow{5}{*}{ middle Badenian } & \multirow{5}{*}{$\mathrm{Ba} 2$} & HST2 & $3^{\text {rd }}$ order highstand systems tract of the sequence Ba2 \\
\hline & & mfs2 & maximum flooding surface of the sequence $\mathrm{Ba} 2$ \\
\hline & & TST2 & $3^{\text {rd }}$ order transgressive systems tract of the sequence $\mathrm{Ba} 2$ \\
\hline & & LST2 & $3^{\text {rd }}$ order lowstand systems tract of the sequence Ba2 \\
\hline & & SB2 & sequence boundary of the sequence $\mathrm{Ba} 2$ \\
\hline \multirow{4}{*}{ lower Badenian } & \multirow{4}{*}{ Ba1 } & HST1 & $3^{\text {rd }}$ order highstand systems tract of the sequence Ba1 \\
\hline & & TST1 & $3^{\text {rd }}$ order transgressive systems tract of the sequence Ba 1 \\
\hline & & LST1 & $3^{\text {rd }}$ order lowstand systems tract of the sequence Ba1 \\
\hline & & SB1 & sequence boundary of the sequence Ba1 \\
\hline
\end{tabular}

Table 1: Overview of Badenian stratigraphic sequences, systems tracts and sequence stratigraphic reference surfaces in the Vienna Basin 

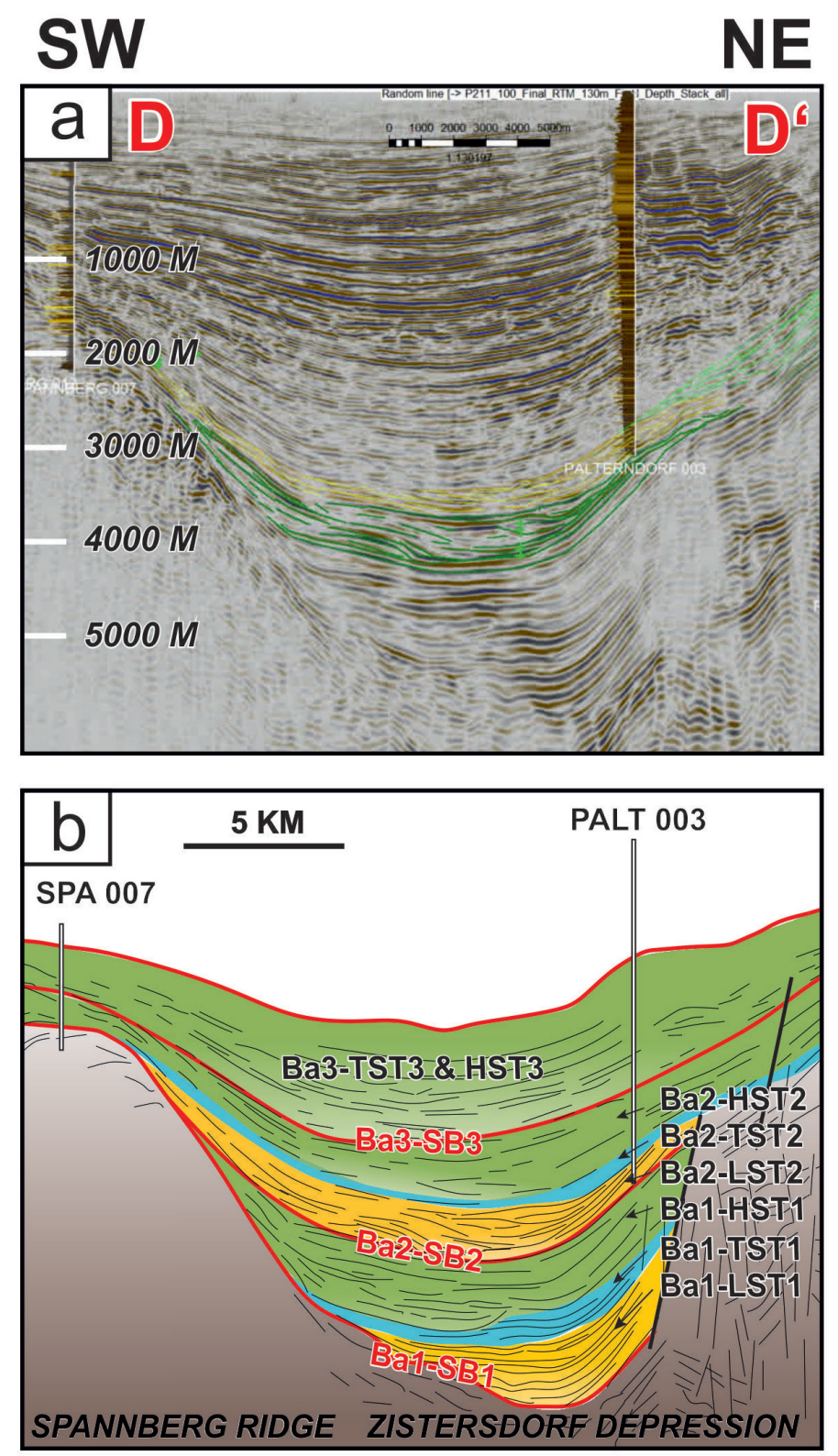

Figure 10: (a) Southwest to northeast seismic profile in the Zistersdorf Depression with spontaneous well logs from the well SPA 007 and PALT 003. Low spontaneous log values are colored in yellow and high spontaneous log values are colored in brown. (b) Badenian systems tracts and sequence boundaries with selected seismic patterns. Seismic patterns of the lower to middle Badenian emphasize a dominant east to northeast sediment transport direction of the paleo-Danube (e.g. prograding clinoforms of the Ba2-LST2).

of the Spannberg Ridge (Strauss et al., 2006; Weissenbäck, 1996; Kováč et al., 2004). This discordance is referred to as the "Styrian Unconformity" (Stille, 1924; Kollmann, 1965; Ebner and Sachsenhofer, 1995). The conglomerates represent fluvial to alluvial braided river systems (Weissenbäck, 1996) defined by low Gamma Ray intervals at the base of the Badenian succession (Fig. 13). The Aderklaa Conglomerate has a south to north sediment transport direction (Weissenbäck, 1996). As shown in Fig. 6a, the pre-Badenian Mistelbach Canyon system linked the alluvial to lacustrine depositional system of the southern Vienna Basin with the marine area in the Alpine-Carpathian Foredeep. This assumption is supported by the presence of the Ivan Canyon outside the northwestern corner of the study area (Dellmour and Harzhauser, 2012; Fig. 6a).
In contrast to the southern study area, early Ba1-LST1 subaerial deposits are missing in the Mistelbach and Reinthal canyons due to deep erosion during younger lowstand systems tracts (Ba1-LST1 or Ba2-LST2). Therefore, the sediment transport direction during deposition of early Ba1-LST1 units in the Mistelbach Canyon and especially in the Reinthal Canyon is still under debate. Taking into account that early Badenian subsidence in the Vienna Basin area is minor and that sediment transport is strongly influenced by the relief created by late Karpatian tectonic uplift (Decker et al., 1996), a general northwestward directed sediment transport is very likely. Hence, we suppose that late Karpatian canyon systems (Mistelbach Canyon and Reinthal Canyon) act as a sub-areal bypass between the Vienna Basin and the North Alpine-Carpathian Foredeep (Fig. 6a). 


\section{SW}
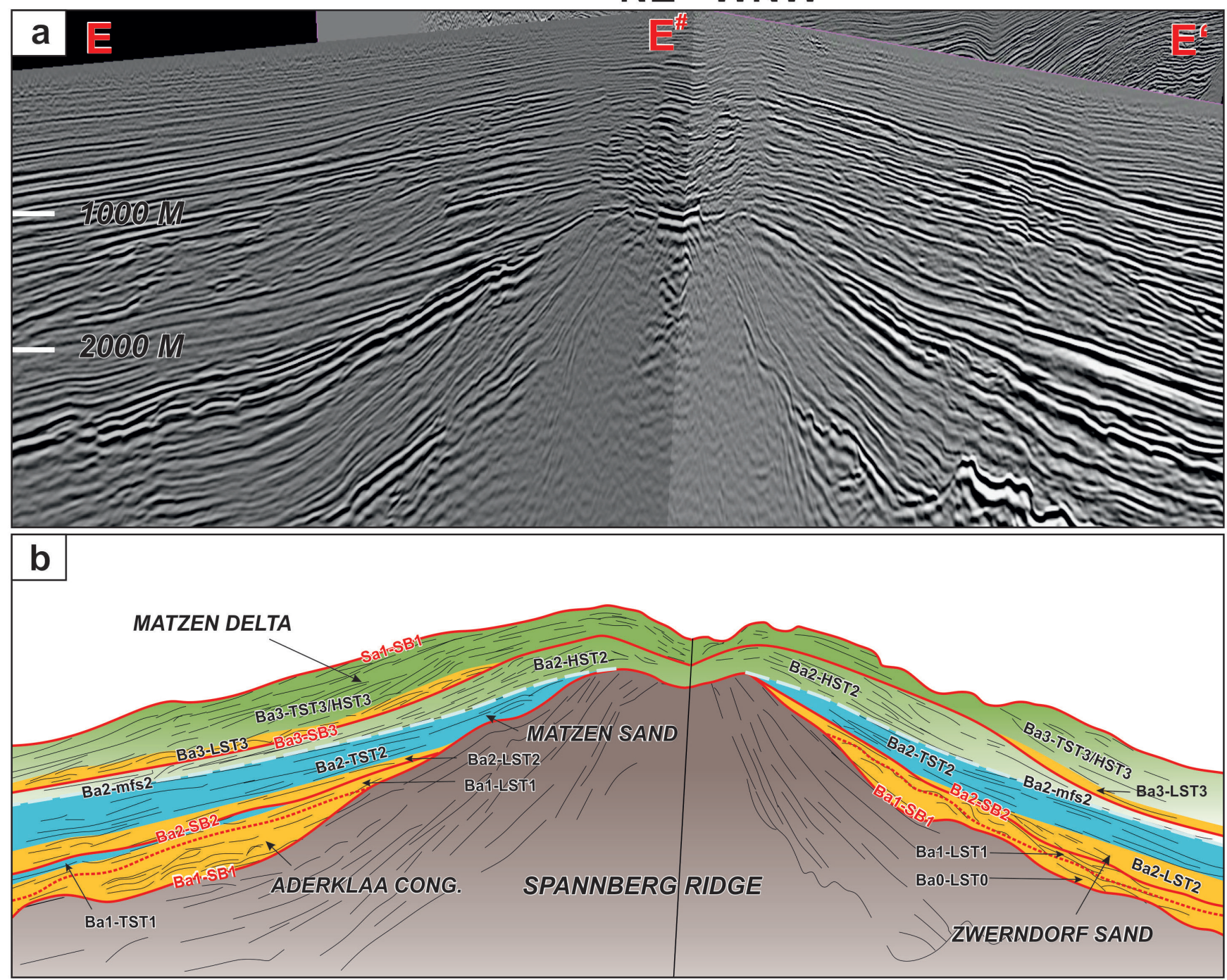

Figure 11: (a) 3D seismic view of the southern and eastern flank of the Spannberg Ridge. (b) The brown shaded area represents pre-Badenian successions of the Spannberg Ridge. Lower Badenian successions mainly consist of remnants of different lowstand systems tracts (e.g. Ba1-LST1 and Ba2-LST2). The dashed red line marks the boundary between the early and late Ba1-LST1 lowstand systems tracts. Middle Badenian successions are strongly affected by the Ba2-TST2 transgressive systems tract and the Ba2-HST2 highstand systems tract. A clear separation between the Ba3-TST3 and Ba3-HST3 cannot be established, thus these two systems tracts are merged together, defining the main part of the upper Badenian succession. Towards the southwest the base of the Badenian consists of the Aderklaa Conglomerate. Towards the east the Ba2-LST2 includes the Zwerndorf Sand. The Matzen Sand forms the onlap termination of the Ba2-LST2, Ba2-TST2 and Ba2-HST2 on the southern flank of the Spannberg Ridge. The Matzen Delta describes the coalesced delta overlying the Spannberg Ridge.

The depositional systems of the Mistelbach Canyon indicate lateral offset when crossing the Steinberg Fault from the footwall to the hangingwall. This reflects early Badenian movements along the sinistral strike-slip fault system of about $2 \mathrm{~km}$ lateral offset. Similar displacements of the Reinthal Canyon along the Steinberg Fault cannot be confirmed, probably because the hangingwall part of the Reinthal Canyon is moved northwards, outside the study area.

During the early Badenian Ba1-LST1 lowstand systems tract a change from strike-slip to extensional faulting (Decker, 1996) caused increasing subsidence rates and the creation of accommodation in the Vienna Basin area. Deposits on the hangingwall of the Steinberg Fault are represented by lowstand delta systems with at least two depocenters towards the northeast and east, outside of the study area (Fig. 6b). Along the southeastern limit of the Spannberg Ridge the Ba1-LST1 floodplains and lacustrine sediments overlie the Aderklaa Conglomerate (Wessely, 2006).

High subsidence rates in the Vienna Basin also cause a change in sediment transport directions between the early Ba1-LST1 and late Ba1-LST1 lowstand systems tracts from a general north-westward to a general eastward direction (Figs. $6 \mathrm{a}$ and $6 \mathrm{~b}$ ). First sediments are transported eastwards by the paleo-Danube into the Vienna Basin, primarily fill the Mistelbach and Reinthal canyons during the late Ba1-LST1 lowstand systems tract (Figs. 4 and 6b). 

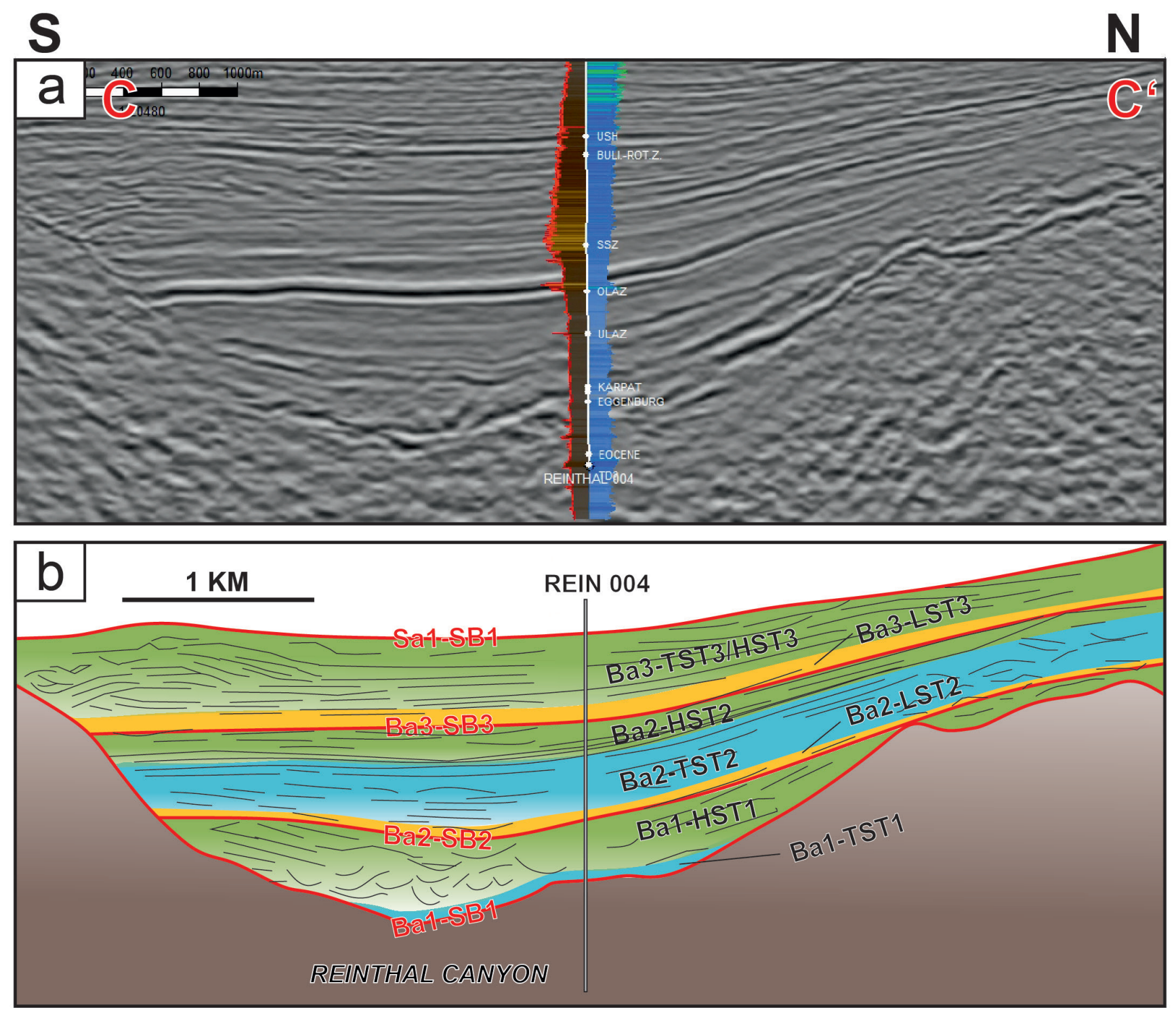

Figure 12: (a) South to north seismic profile in the Reinthal Canyon perpendicular to the sediment transport direction with spontaneous (red) and resistivity logs of the key well REIN 004. Low well log values of the spontaneous log are colored in yellow and of the resistivity in bright blue. High well log values of the spontaneous log are colored in brown and of the resistivity in green. (b) Badenian systems tracts and sequence boundaries with selected seismic stratal patterns.

\subsection{Depositional system of the Ba1-TST1 lower Badenian transgressive systems tract}

The Ba1-TST1 transgressive systems tract is marked as blue shaded polygons in the seismic profiles shown in Figs. 4c, 5b, 10b, $11 \mathrm{~b}$ and $12 \mathrm{~b}$. It overlies sediments of the Ba1-LST1 (orange shaded polygons). A paleogeographic map for the Ba1-TST1 transgressive systems tract is provided in Fig. 6c.

Initiated by a change from a compressional and sinistral strike slip regime to an extensional regime (Hölzel et al., 2008), major accommodation is created in the Vienna Basin area by the increase of subsidence along major normal faults like the Steinberg Fault (Wessely, 2006). Former possible drainage systems of the Vienna Basin area, heading north-westwards into the North Alpine-Carpathian Foreland Basin (Grunert et al., 2013) or towards north into the Polish Carpathian Foredeep
(Meulenkamp et al., 1996, Picha et al., 2006), are flooded by the onset of the early Badenian transgression. Increasing subsidence of the Vienna Basin during the early Badenian also caused significant paleogeographic changes in the Western Carpathians (Kováč et al. 2004), where former alluvial and lacustrine environments with pronounced erosion during late Karpatian compressional tectonics (Kováč et al., 2007) changed to major marine depositional environments.

The Ba1-TST1 transgressive systems tract is defined in the $3 \mathrm{D}$ seismic survey by parallel seismic reflectors with backstepping onlaps in all sub-basins. Based on well logs (e.g. Fig. 13), the transgressive systems tract is dominated by shale bearing intervals. Obviously, Ba1-TST1 is still strongly influenced by the early Miocene paleo-topography (Fig. 4c), hindering clear well and seismic cross-correlations. 


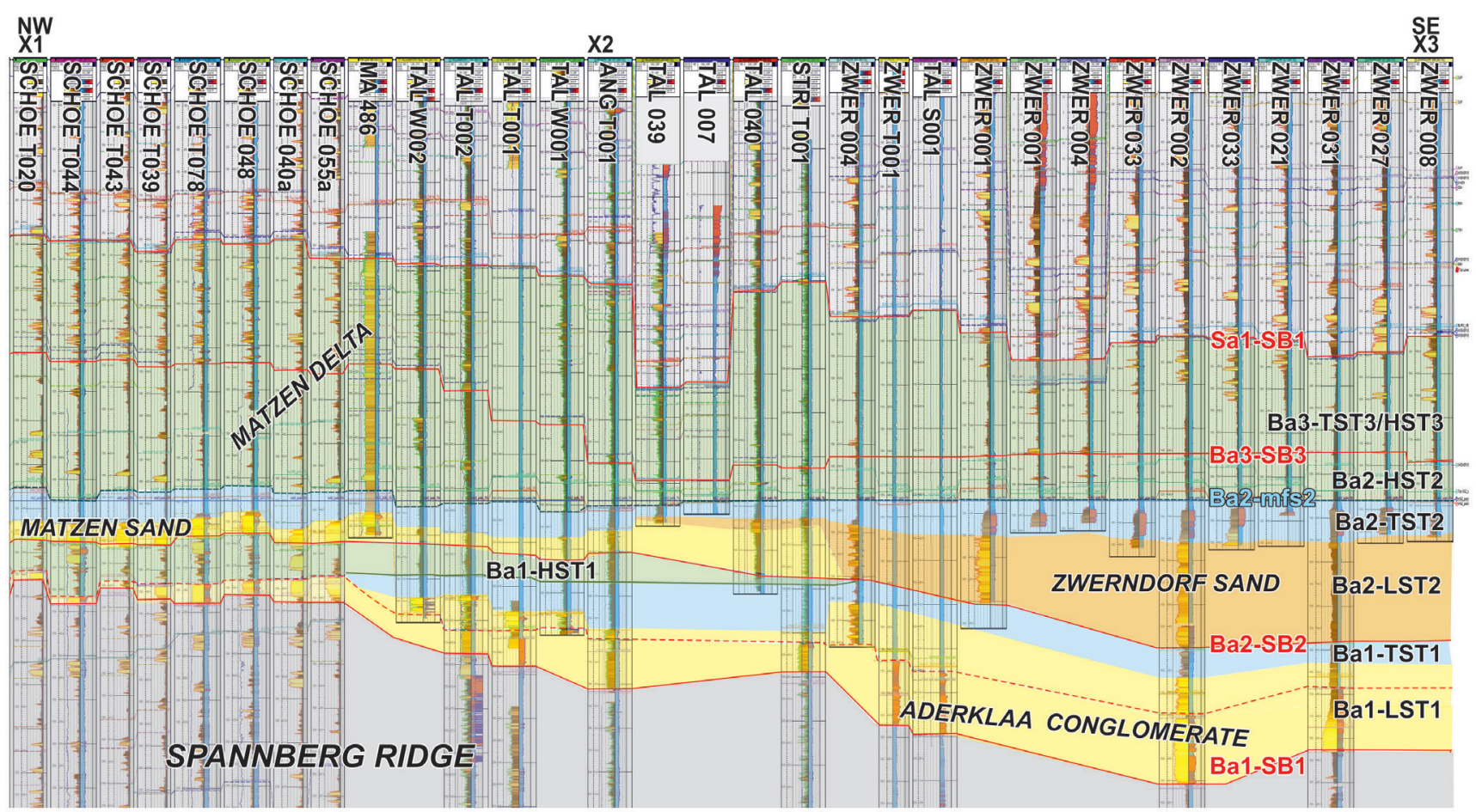

Figure 13: Well cross-section (spontaneous logs in red, gamma ray logs in green and resistivity in blue) on the southeastern flank of the Spannberg Ridge with Badenian systems tracts. Low well log values of the spontaneous log and the gamma ray log are colored in yellow and of the resistivity in blue. High well log values of the spontaneous log and the gamma ray log are colored in brown and of the resistivity in red. The lowermost systems tract of the Badenian (early Ba1-LST1, yellow area below the red dashed line) represents alluvial and fluvial deposits of the early stage of the Vienna Basin (Aderklaa Conglomerate). Accommodation southeast of the Spannberg Ridge forms a depocenter until middle Badenian (e.g. Ba2-LST2, Zwerndorf Sand) with contemporaneous shallow marine deposits along the Spannberg Ridge (e.g. Matzen Sand). At the end of Ba2-TST2 or beginning of Ba2-HST2, the Spannberg Ridge becomes drowned, and a new delta system is established (Matzen Delta system).

In the northern part of the study area, sediment accumulation during Ba1-TST1 is restricted to sub-basins developed on the hangingwall of the Steinberg Fault (Fig. 5, Mühlberg High and Rabensburg Horst) and in the thalweg of the Reinthal and Mistelbach canyons on the footwall (Fig. 12b). The central part consistes of subaerial deposits restrained to the Spannberg Ridge, acting as a paleo-high separating the northern and southern part of the study area (Fig. 4c). Sedimentation persists in each of these sub-basins during the entire early Badenian, although restricted shallow water connections are expected.

\subsection{Depositional system of the Ba1-HST1 lower Badenian highstand systems tract}

The Ba1-HST1 highstand systems tract is marked as green shaded polygon in Figs. 4c, 5b, 10b and 12b. It overlies the Ba1-TST1 (blue shaded polygons) and underlies the Ba2-SB2 (red polyline). A paleogeographic map for Ba1-HST1 transgressive systems tract is provided in Fig. 6d.

This systems tract is strongly related to the onset of high sediment support from the west by the paleo-Danube (Fig. 6d). Even though sediments of this river system are deposited in earlier systems tracts (Ba1-LST1, Ba1TST1), the sediment load increases dramatically within Ba1-HST1. For instance in the Mühlberg area, where the Ba1-TST1 accumulates sediments of approximately $50 \mathrm{~m}$ and the Ba1-HST1 approximately $350 \mathrm{~m}$ (Fig. 4c). The
Mistelbach Canyon and especially the Reinthal Canyon show progradational clinoforms in seismic data heading towards the Vienna Basin. Northern sub-basins of the Zistersdorf Depression and Mühlberg High are probably connected via a shallow marine seaway (Fig. 6d).

The central part is still dominated by the Spannberg Ridge, separating the northern and southern part of the Vienna Basin (Fig. 4c), with a possible shallow marine linkage along the eastern limit of the Spannberg Ridge from the Zistersdorf Depression to the Marchfeld Depression. This causes limited sediment input into the southern basin. Therefore, and because of regional subsidence, the creation of accommodation outpaces sediment accumulation south (and east) of the Spannberg Ridge. As a consequence, no significant difference exists between the underlying Ba1-TST1 and the Ba1-HST1 along the margin of the Spannberg Ridge and both systems tracts are characterized by onlap terminations (Fig. 4c). Hence, a clear boundary between the Ba1-TST1 and the Ba1-HST1 cannot be observed in the Marchfeld Depression, where sediment influx to the basin floor is continuous, but limited and seems to be related to a southern or eastern hinterland (Fig. 6d).

\subsection{Depositional system of the Ba2-LST2 middle Badenian lowstand systems tract}

The Ba2-LST2 lowstand systems tract is marked as orange polygon area in Figs. 4c, 5b, 10b, $11 \mathrm{~b}$ and 12b following 


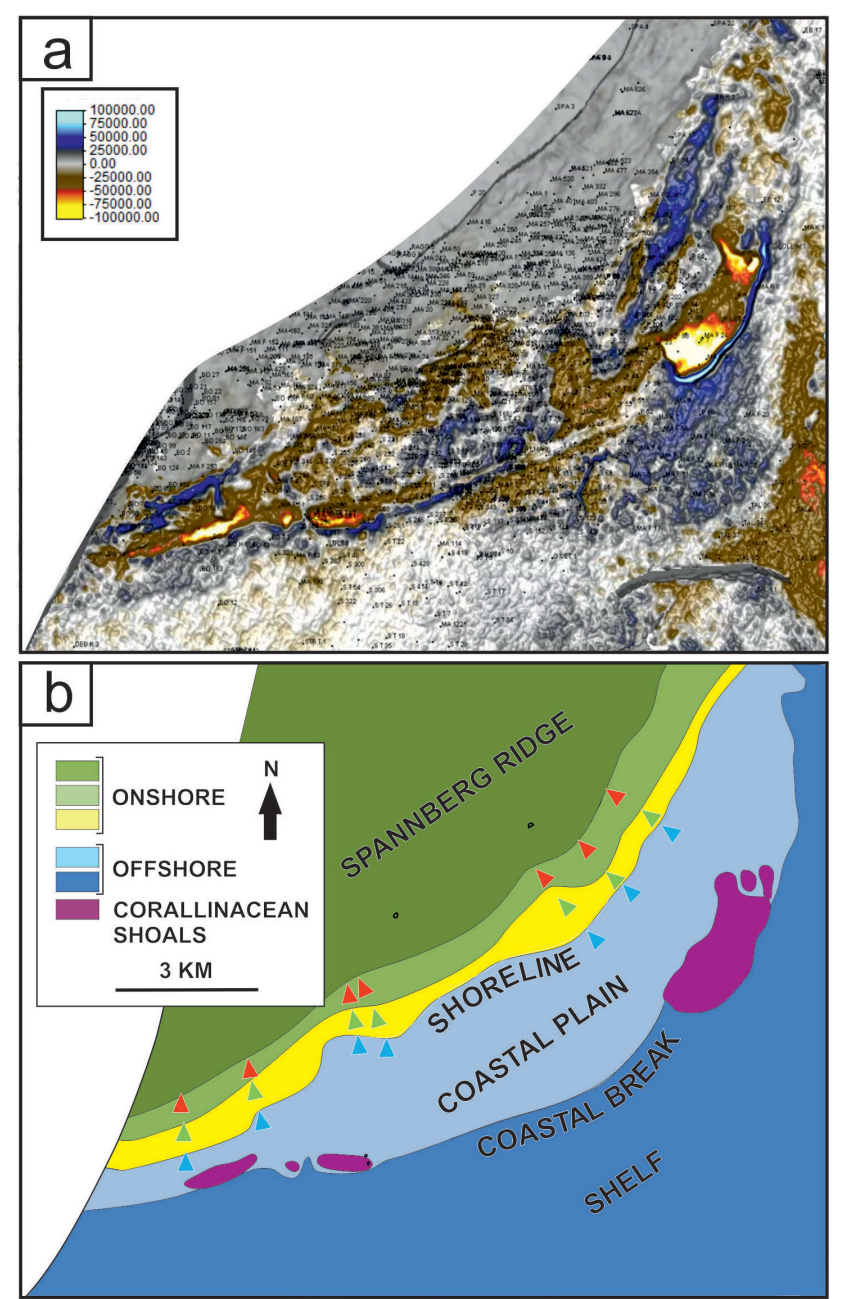

Figure 14: (a) Seismic impedance attribute map of the VBSM seismic survey below the reference horizon Ba2-mfs 2 on the southeast rim of the Spannberg Ridge. The displayed horizon represents a distinctive paleogeographic map of the Ba2-TST2 transgressive systems tract. The grey shaded zone in the northern part represents the contemporaneous onshore area of the Spannberg Ridge. Abbreviated wells names are plotted in black. (b) Green and yellow shaded polygons represent the onshore area of the Spannberg Ridge. The blue shaded polygons represent the offshore area, with corallinacean shoals (magenta) close to the coastal break. Succeeding northward transgressive backstepping trajectory is marked by green and red arrows.

above the Ba2-SB2 sequence boundary. Paleogeographic maps of this systems tract are provided in Fig. 7a (early Ba2-LST2) and Fig. 7b (late Ba2-LST2).

The pre-Badenian paleo-topography has largely backfilled or become overprinted by Badenian south-southwest to north-northwest extensional fault systems (Hölzel et al., 2008). Accommodation is strongly fixed to newly developed graben and horst structures along major fault systems like the Steinberg Fault.

In former publications this lowstand systems tract is considered a part of the Sandschaler (now Spirorutilus) Zone (SSZ), the local equivalent to the Jakubov Formation (Fig. 3). This biostratigraphic unit is linked to specific lithostratigraphic units (e.g. the Matzen Sand in Fig. 3; Kreutzer, 1986). Based on that cross correlation, the SSZ is defined either by biostratigraphy (based on well cores) or lithostratigraphy (based on well logs and seismic data). Unfortunately the available OMV internal SSZ database does not distinguish between either classifications. Using the predefined intervals of the SSZ and comparing them with new seismic and well log data, a discrepancy between biostratigraphy, lithostratigraphy and sequence stratigraphic classifications becomes obvious. Sedimentation of the SSZ commences earlier in the south than in the north. Based on the new sequence stratigraphic model, the SSZ is contemporaneous to the Ba2-LST2, Ba2-TST2, Ba2-HST2 systems tracts in the south, and to the upper $\mathrm{Ba} 2-\mathrm{TST} 2$ and Ba2-HST2 systems tracts in the north. This mismatch reflects the fact that fossil assemblages of the SSZ are related to specific ecological conditions, which may occur independently of sea-level fluctuation.

In the Reinthal Canyon the Ba2-LST2 systems tract is characterized by northeast prograding clinoforms with offlap terminations. The distal part of this lowstand delta system seems to be located northeast of the study area in the Czech Republic (Fig. 7a). In the Mühlberg High area cuttings and core data characterize this systems tract as a delta complex, with indication of paleosols.

During early stages of the Ba2-LST2, a lowstand delta system forms in front of the Mistelbach Canyon. Sediment bypass across the Zistersdorf Depression towards the east enables accumulation of turbiditic Zwerndorf Sand along the eastern flank of the Spannberg Ridge (Figs. 3, 7a and 11b). Later stages of this lowstand systems tract are represented by east to northeast prograding clinoforms in the Zistersdorf Depression (Fig. 10b). This reflects ongoing subsidence along the Steinberg Fault, which results in trapping of sediments within the Zistersdorf Depression. Hence, sediment transport towards the east becomes cut off (Fig. 7b). To the south, the Ba2-LST2 systems tract onlaps the Spannberg Ridge, thus this ridge still separates the northern and the southern part of the study area (Fig. 4c). In the southern part of this ridge mainly proximal ravinement sediments are deposited with correlative condensed shale bearing successions in the Marchfeld Depression. In the northeast of the Marchfeld Depression these proximal sediments merge with the lowstand delta system deposits of the Zwerndorf Sand.

\subsection{Depositional system of the Ba2-TST2 middle Badenian transgressive systems tract}

The Ba2-TST2 transgressive systems tract is marked in Figs. 4c, 5b, 10b, 11b, 12b and 15b as blue shaded polygons overlaying the Ba2-LST2 (orange polygons). Fig. 7c provides a paleogeographic map for the Ba2-TST2 transgressive systems tract. During Ba2-TST2, depocenters related to pre-Badenian topography no longer exist, but new accommodation is provided by horst and graben structures resulting from ongoing fault activity along the Steinberg Fault. Despite eustatic sea-level changes, depositional systems are mainly controlled by the interplay between ongoing extensional faulting, represented by dominant south-southwest to north north-east striking fault systems, and sediment influx of the paleo-Danube. 

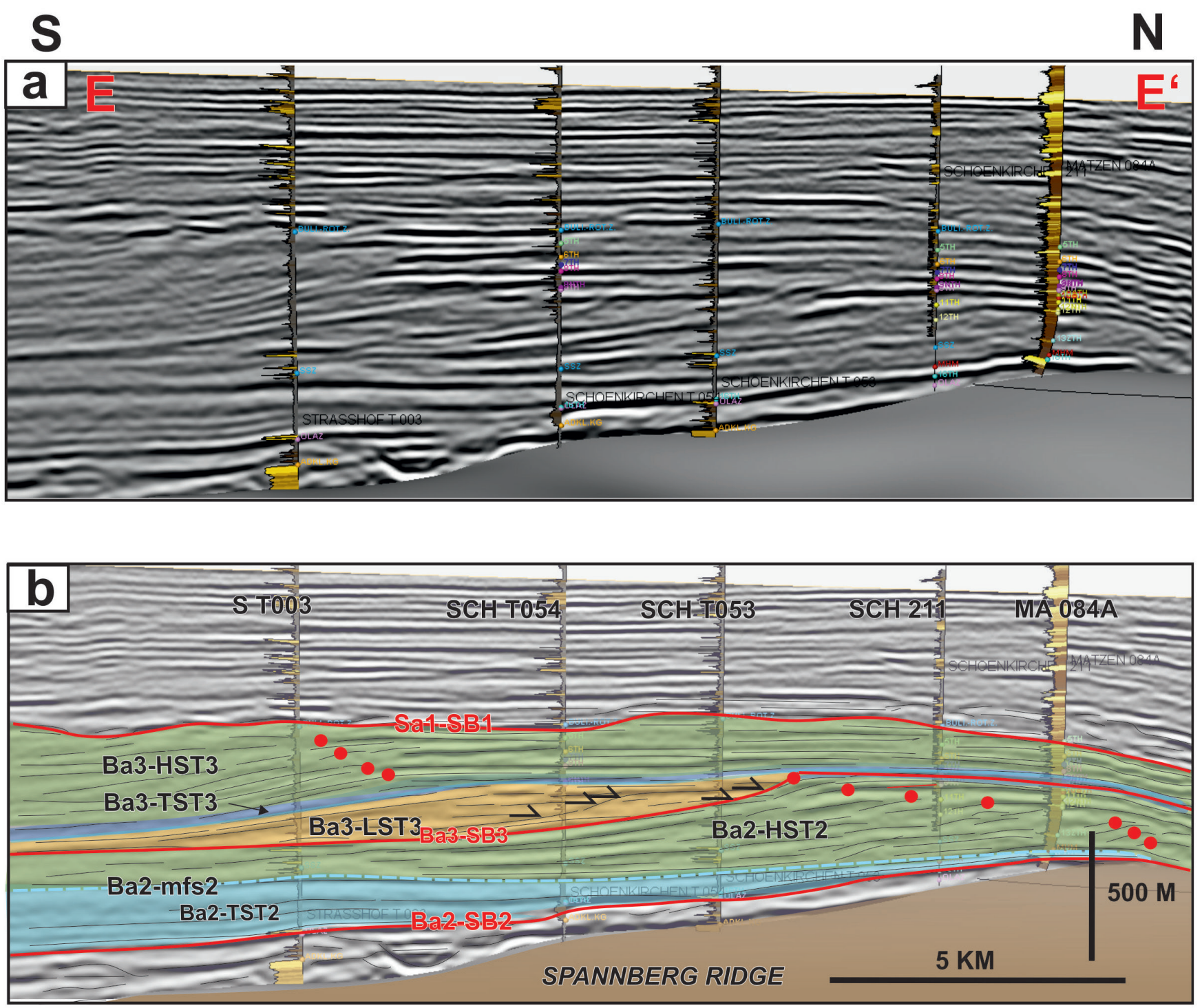

Figure 15: (a) South to north seismic profile of the Matzen Delta on the southern flank of the Spannberg Ridge with spontaneous logs from key wells. Low spontaneous log values are colored in yellow and high spontaneous log values are colored in brown. (b) Systems tracts of the middle and upper Badenian successions. The base of the generally progradational delta systems is defined by the Ba2-mfs2 (maximum flooding surface of the Ba2 sequence). The change from sequence Ba2 to Ba3 is initiated by the sea-level drop during Ba3-LST3 (early lowstand systems tract), manifested by offshore terminations marked by black arrows and a sequence boundary (Ba3-SB3) at the base.

The middle Badenian systems tract Ba2-TST2 represents the first event where all sub-basins merge within a uniform offshore area. However, even though the Vienna Basin is entirely marine, variations in the availability of accommodation reflect onset of new depocenters. Therefore, continuous seismic reflectors or distinctive well log patterns are not available to define reference horizons. Consequently, each of the horst-graben structures must be reconstructed independently. The southern rim of the Spannberg Ridge, where the transgressive backstepping system creates accommodation, may serve as an example. Here the primary shoreface (deltaic barrier island) systems are transformed during transgression into bioturbated shelfal sand shoals (Kuffner, 2017). Fig. 14a shows a seismic impedance attribute map below the Ba2-mfs2 (maximum flooding surface). The blue arrows indicate the onlap on the Spannberg Ridge and the green and red arrows the following backstepping of the shoreline.
Seismic impedance attributes of a seismic depth slice indicate different depositional systems including a coastal environment, longshore lineaments along the shoreline break, corallinacean shoals (Knox et al., 2000) and shelf areas (Fig. 14b). The spatial view of this area in Fig. 11b emphasises seismic patterns along southwest and east-southeast trending profiles. Obvious are the lateral onlaps of this systems tract on the southern and eastern flank of the Spannberg Ridge. The Ba2-mfs2 (maximum flooding) represents the uppermost onlap of the Ba2TST2, terminating near the crest of the Spannberg Ridge (Fig. 11b). Even though the Spannberg Ridge is not entirely drowned during this systems tract, the subdivision of the central part of the Vienna Basin into a southern and northern depositional system ceases (Fig. 4c). Due to low sediment influx, corallinacean shoals develop on the eastern flank of the Spannberg Ridge and on the footwall of the Steinberg Fault (e.g. Reinthal Canyon; Fig. 7c). 

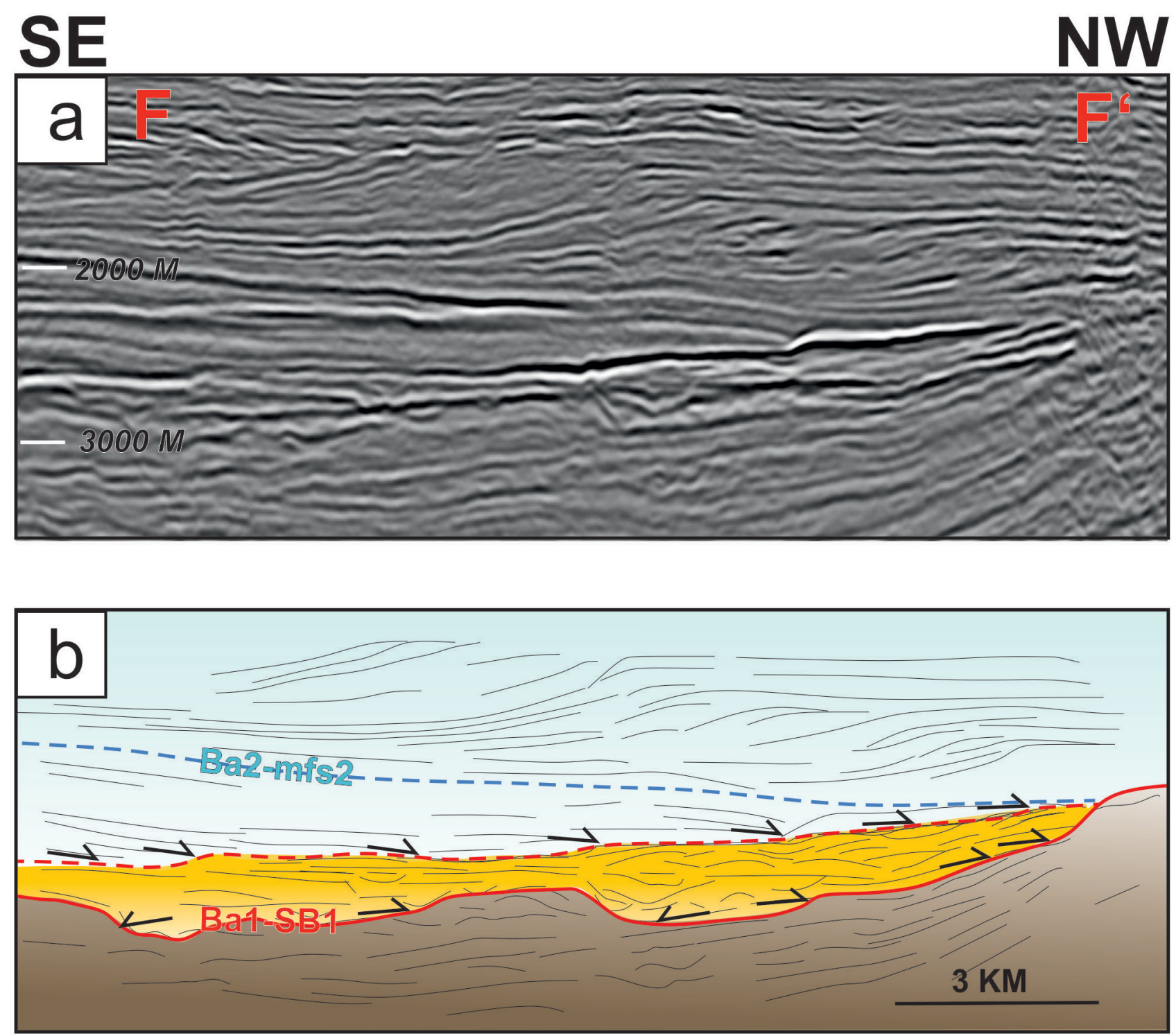

Figure 16: (a) A southeast to northwest seismic profile of the Matzen Delta on the southeastern flank of the Spannberg Ridge. (b) The sequence boundary of the Ba1-SB1 (solid red line). Boundary between the early and late Ba1-LST1 lowstand systems tract are marked with a dashed red line; black arrows display onlaps. Obvious is the dominant erosional surface of the Ba-SB1 with stratal truncation of pre-Badenian successions (brown polygon). The orange polygon represents the subaerial deposits of the Aderklaa Conglomerate (early Ba1-LST1 sequence). The blue polygon represents the marine deposits of the $\mathrm{Ba} 1, \mathrm{Ba} 2$ and $\mathrm{Ba} 3$ sequences.

Graben structures like in the Mühlberg High, Zistersdorf Depression or Marchfeld Depression, are filled with mudrich condensed sections, represented by bright parallel seismic reflectors and high Gamma Ray or Spontaneous Potential well log values (Figs. 13). Backstepping ravinement surfaces are developed on local highs like on the hangingwall of the Steinberg Fault. A prominent representative of this depositional system is the Matzen Sand (or 16.TH) on the southern flank of the Spannberg Ridge (Fig. 7c and 11), which is the most important hydrocarbon reservoir horizon in the Matzen field (Kreutzer, 1992; Fuchs and Hamilton, 2006).

Seismic mapping of the Ba2-mfs2 maximum flooding surface is also crucial for the recognition of the early/ middle Badenian configuration of the Vienna Basin. Its regional extension, low sedimentation rate and reasonably homogenous depositional system allow flattening of the seismic data cube. By using this approach, depocenters of lower/middle Badenian sub-basins become obvious (e.g. Figs. $4 \mathrm{~b}$ and $4 \mathrm{c}$ ).

\subsection{Depositional system of the Ba2-HST2 middle Badenian highstand systems tract}

The Ba2-HST2 highstand systems tract is marked as green shaded polygons in Figs. 4c, 5b, 10b, 12b, 15b overlying the Ba2-TST2 (blue polygons). Paleogeographic maps of the Ba2-HST2 transgressive systems tracts are provided in Figs. $8 \mathrm{a}$ and $\mathrm{b}$.

During the Ba2-TST2 systems tract, drowning of the Palterndorf High between the Mühlberg High and the Zistersdorf Depression merge the northern sub-basins to one depositional system (see Fig. 2 for position of Palterndorf High). Ongoing subsidence during the Ba2HST2 systems tract merges the northern and southern 
part of the central Vienna Basin by drowning the Spannberg Ridge (Fig. 8b).

In the northern part, early Ba2-HST2 northeast prograding clinoforms of the Mühlberg Delta overlie corallinacean shoals in the Reinthal Canyon (Fig. 8a). Ongoing eastward progradation of this delta system during late stages of the Ba2-HST2 is represented by proximal shallow marine channels system in the Reinthal Canyon and the Mühlberg High with distal delta break and slope facies passing into the Czech Republic towards the north. A transition of the northern Mühlberg Delta and southern Zistersdorf Delta of the paleo-Danube Delta system is developed on the northern flank of the Zistersdorf Depression, represented by shallow marine flood plain deposits (Fig. 8b).

The southern branch of the paleo-Danube uses the former drainage system of the reactivated Mistelbach Canyon as an entry point and fills the subsiding Zistersdorf Depression during the early Ba2-HST2 systems tract (Zistersdorf Delta; Fig. 8a).

Southward directed clinoforms in the upper part of the Ba2-HST2 systems tract cover the top of the Spannberg Ridge (Figs. 4c, 11b, 15b). This shows that the Spannberg Ridge is finally drowned (Fig. 8b). These clinoforms define the base of the south eastward prograding Matzen Delta system, which replaces the former northeast trending Zistersdorf Delta system (Figs. 8a, b). The prograding Matzen Delta system of the late Ba2-HST2 results in major sediment influx of the paleo-Danube into the sub-basins south and east of the Spannberg Ridge (Figs. 4c and 11b). Therefore, the southern flank of the Spannberg Ridge, the Gr. Engersdorf Depression and the Marchfeld Depression primarily consist of distal delta slope and basin floor deposits of the genetically related Matzen Delta system.

\subsection{Depositional system of the Ba3-LST3 upper Badenian lowstand systems tract}

The Ba3-LST3 lowstand systems tract is marked as orange shaded polygons in Figs. 4c, 5b, 11b, 12b and 15b overlaying the Ba2-HST2. A paleogeographic map is provided in Fig. 9a.

The sea-level fall associated with the Ba3-LST3 is camouflaged by strong subsidence due to the ongoing extensional subsidence of the Vienna Basin (Hölzel et al., 2008). Thus, defining the Ba3-LST3 lowstand systems tract, especially in the northern part, is challenging. Core intervals, taken in the Mühlberg and Rabensburg area, indicate the presence of paleosol and lignite near the Ba3SB3 sequence boundary (Harzhauser et al. 2018, Kuffner, 2012). In the Zistersdorf Depression the subsidence rate is almost equal to sedimentation rate. Thus, a distinctive sequence boundary or lowstand systems tract cannot be defined based on seismic data. Lowstand deposits are delimited to the southern part of the Spannberg Ridge, exposed as south heading clinoforms (Figs. 4, 11b and 15b). Offlap terminations of these clinoforms towards the north (black arrows in Fig. 15b) indicate a falling stage system tract related to sea-level fall. Genetically related subaerial exposure of the proximal northwestern part of
Spannberg Ridge or distal basin floor lowstand deposits cannot be identified.

\subsection{Depositional system Ba3-TST3/HST3 upper Badenian transgressive/highstand systems tract}

The uppermost transgressive and highstand systems tracts are merged together to one Ba2-TST3/HST3 systems tract. This combined systems tract is marked by green shaded polygons in Fig. 4c, 10b, 11b and 12b overlaying the Ba3-LST3. A paleogeographic map for the Ba3TST3/HST3 systems tracts is provided in Fig. $9 \mathrm{~b}$.

Increasing subsidence of the Vienna Basin effectively overprints the global $3^{\text {rd }}$ order sea-level changes (Hölzel et al., 2008). Especially at slow sea-level rise, local sediment rates outpace accommodation; local high subsidence rates could inverse this system.

Several approaches are applied to distinguish between the transgressive (Ba3-TST3) and highstand systems tracts (Ba3-HST3). Progradational to aggradational delta plain environments characterize the depositional system of both systems tracts in the large parts of the Vienna Basin. Backstepping systems, such as transgressive ravinement surfaces on top of the Ba3-LST3 lowstand systems tract, are used to define the base of the Ba3-TST3 (Fig. 15b). Maximum flooding surfaces (mfs) can be identified on seismic or well log data on different localities, but a regional isochron boundary between the Ba3-TST3 and Ba3-HST3 cannot be established.

Shallow marine deposits of the united Matzen and Mühlberg Delta systems dominate the sedimentary record of the upper Badenian units in the Vienna Basin (Fig. $9 b)$. In the northern part shale rich successions on top of the Ba3-LST3 are dedicated to the Ba3-TST3 (Fig. 5b). Above this shale bearing interval mainly aggradational parasequences represent fine grained delta plain deposits. A minor retrogradational parasequence trend at the top of the Badenian is related to increasing subsidence of the hanging wall of the Steinberg Fault. Aggradational parasequences in the Zistersdorf Depression represent shale rich delta floodplains of the transition zone between the Matzen and Mühlberg deltas (Fig. 10). Distinctive transgressive backstepping systems on the southern flank of the Spannberg Ridge represent the Ba3-TST3 (Fig. 15b) and include prominent hydrocarbon reservoirs (9.TH and 8.TH).

West of the Spannberg Ridge the overlaying Ba3-HST3 of the Matzen Delta is composed of proximal stacked channels systems, on the eastern and southern flank of the Spannberg Ridge with east and south-verging distal clinoforms (Figs. 11b, 15b).

Truncations, like incised valleys on top of the uppermost Badenian Ba3-HST3 systems tract, indicate a subsequent early Sarmatian sea-level fall (Figs. 11b, 15b).

\section{Discussion}

In this study we present paleogeographic maps for the central and northern part of the Austrian Vienna Basin, based on a sequence stratigraphic model for the 
Badenian infill. Our data confirm the model of Strauss et al. (2006), which is based on seismic data from the southern Vienna Basin. Thus, the herein described $\mathrm{Ba} 1, \mathrm{Ba} 2$ and $\mathrm{Ba} 3$ sequences are full equivalents of the eponymous sequences of Strauss et al. (2006). This shows that sea-level variations are traceable throughout the entire Vienna Basin although they may be masked to some degree by local tectonics (e.g. Ba2/Ba3 boundary).

Earlier applications of sequence stratigraphy to the Vienna Basin (e.g. Kováč et al., 2004; Strauss et al., 2006) link the observed sequences to the global $3^{\text {rd }}$ order sea-level sequences of Haq et al. (1988) and Hardenbol et al. (1998); see Fig. 3. Thus, Ba1, Ba2 and Ba3 may be expressions of the $3^{\text {rd }}$ order sequences TB2.3, TB2.4 and TB2.5 of Haq et al. (1988), respectively. The base of the $\mathrm{Ba} 3$ sequence correlates with the Ser1/Ser2 sequence boundary of Hardenbol et al. (1998) coinciding with the Langhian/Serravallian boundary (Harzhauser et al., 2018).

One of the remaining uncertainties concerns the status of the early Ba1-LST1 lowstand systems tract and the relation with the late Ba1-LST1 lowstand systems tract. This topic will be discussed in the following subsection. Additional subsections deal with the evolution of Badenian delta systems, the role of the middle Badenian maximum flooding surface and syndepositional tectonics.

\subsection{Initial stages of the Badenian}

The fluvial Aderklaa Conglomerate (Fig. 3), attributed to the early Ba1-LST1 lowstand systems tract, is widespread south of the Spannberg Ridge (Weissenbäck, 1996). It represents the oldest sediments deposited above tilted Ottnangian and Karpatian units (Kreutzer, 1986; Kreutzer and Hlavay, 1990). The age of the early Ba1-LST1 (late Karpatian or earliest Badenian) is unclear, because of the lack of reliable biostratigraphic data in the fluvial depositional system. In any case, the early Ba1-LST1 cannot represent the $3^{\text {rd }}$ order sequence between Bur4 and Bur5/Lan1, as this represents more or less the entire Karpatian (cf. Piller et al., 2007). Therefore, the Aderklaa Conglomerate may represent an early 4th order lowstand systems tract of the Ba1 sequence.

Alternatively, the Aderklaa Conglomerate may be considered as relict sediments of a deep subaerial lowstand systems tract at the Karpatian/Badenian boundary. Minor angular unconformities between the subaerial early Ba1LST1 and the overlying marine late Ba1-LST1 (Fig. 16) are evidence for ongoing tectonic activity. Hence, the shift from subaerial to marine environments probably results from the interplay of syntectonic activity and the change of sediment input. Thus, the early Ba1-LST1 is dedicated to Badenian, above the Bur5/Lan1 sequence boundary.

The early Ba1-LST1 reflects a genetically related depositional system of braided river systems in the entire Vienna Basin, with drainage (canyon) systems through the Waschberg Zone towards the North Alpine-Carpathian Foredeep. Hence, the Aderklaa Conglomerate grades laterally into the littoral Ivan Formation, filling the base of the Ivan Canyon in the North Alpine-Carpathian Foreland Basin (Dellmour and Harzhauser, 2012; Harzhauser et al., 2019).
Evidence for subaerial early Ba1-LST1 conglomerates in the northern part of the Austrian Vienna Basin is missing. The lack of subaerial deposits north of the Spannberg Ridge is explained by bypassing of alluvial deposits or by deep erosion of the following late Ba1-LST1 sequence. The postulated non-marine early Ba1-LST1 environment emphasizes restricted accommodation caused by a dramatic sea-level fall or tectonic uplift. Tectonic models (Decker et al., 1996) indicate uplift of the Vienna Basin area during the Karpatian piggy-back basin phase. In this context, the early Ba1-LST1 may represent late Karpatian deposits.

A major change in depositional environments in the Vienna Basin occurs between early Ba1-LST1 and late Ba1-LST1. It is related to extensional tectonic activity caused by lateral eastward extrusion of the Eastern Alps (Ratschbacher et al., 1991a,b; Decker et al., 1996) and contemporaneous subsidence in the Vienna Basin. It causes the change of prevailing northwest directed sediment transport directions in the Vienna Basin area (early Ba1LST1; Fig. 6a) to eastward directed sediment transport directions (late Ba1-LST1; Fig. 6b). Within the context, the former Karpatian drainage systems of the paleo-Danube towards the North Alpine-Carpathian Foredeep (e.g. Ivan Canyon; e.g. Dellmour and Harzhauser, 2012) become extinct and switch towards to the newly created Badenian accommodation in the Vienna Basin, using the Mistelbach and Reinthal canyon systems as entry points into the ba$\sin$. Therefore the late Ba1-LST1 sequence represents the oldest deposits of the paleo-Danube in the Vienna Basin.

\subsection{Delta evolution}

As shown above, the oldest delta sediments, sourced by the paleo-Danube, accumulate during late Ba1-LST1 (Fig. 6b). Previous depositional models describe one dominant Badenian delta system (e.g. Jiríček and Seifert, 1990). In contrast, new 3D seismic data indicate several delta systems with asynchronous development.

The paleo-Danube splits into two branches near the western edge of the study area. The northern branch uses the Reinthal Canyon as entry point into the Vienna Basin and the southern branch the Mistelbach Canyon. Depending on tectonic subsidence, either the northern or the southern branch is more active.

The Ba1-LST1 lowstand delta fills accommodation provided by the onset of extensional fault tectonics. Main subsidence and accumulation of delta sediments occur east of the study area in the Slovak Republic. In contrast, the northern part of the Austrian Vienna Basin is mainly used as bypass zone with restricted sediment accumulation in the eastern prolongation of the Mistelbach and Reinthal canyons. Seismic data from the Slovak part are not available. Therefore, the position of the depocenter shown in Figs. $6 \mathrm{~b}$ to $6 \mathrm{~d}$ is speculative.

Ongoing subsidence on the hanging wall of the Steinberg Fault during Ba1-HST1 and Ba2-LST2 enables significant sediment entrapment in the northern part of the study area. Despite ongoing subsidence, Karpatian paleo-topography still influences the distribution of the 
sediments. Hence, the Zistersdorf Delta (in front of the Mistelbach Canyon) and the Mühlberg Delta (in front of the Reinthal Canyon), accumulate in areas of high subsidence rates and pre-Badenian syncline structures (Zistersdorf Depression and Mühlberg High, respectively). Both delta systems show lateral onlaps on the Palterndorf High, separating the Zistersdorf Depression and Mühlberg High (for position see Fig. 6b), till the end of Ba2LST2 (Fig. 7b).

During middle Badenian time the Reinthal and Mistelbach canyons, as well as the Palterndorf High, are drowned (Ba2-TST2; Fig. 7c). However, because of differential compaction and ongoing uplift of the footwall of the Steinberg Fault along the Zistersdorf segment (opposite the Zistersdorf Depression), the two branch system remains active during Ba2-HST2.

The Zistersdorf Delta is bordered in the south and southeast by the Spannberg Ridge during the early Ba2HST2 (Fig. 8a) and sediments are deposited in or east of the Zistersdorf Depression. During the late Ba2-HST2 (Fig. 8b) the drowning of the Spannberg Ridge initiates a clockwise rotation of the Zistersdorf Delta. Thus, the former Zistersdorf Delta transforms into the Matzen Delta covering the Spannberg Ridge and filling accommodation in the Gr. Engersdorf Depression and the Marchfeld Depression (Figs. 8b and 9b).

The Mühlberg Delta is restricted to the western sector of the Reinthal Canyon during the early Ba2-HST2 (Fig. 8a), but progrades rapidly eastwards during the late Ba2-HST2 (Fig. 8b). Although drowning of the Palterndorf High creates one uniform accommodation, the Zistersdorf and Mühlberg deltas remain separated by a transition zone with flood plain or shallow marine deposits during Ba2-HST2 (Fig. 8b).

This delta system is temporarily interrupted during the Ba3-LST3 sea-level fall, when sediment accumulation is restricted to the eastern depocenter of the former Zistersdorf Delta system (Fig. 9a). During Ba3-TST3/HST3, sediment transport from the hinterland is mainly along to the southern branch of the paleo-Danube. Thus the Matzen Delta becomes the dominant delta system in the Austrian Vienna Basin while the Mühlberg Delta becomes less important.

\subsection{The middle Badenian transgression (Ba2-TST2) in the Vienna Basin}

The Ba1-TST1 transgressive systems tract represents the first Badenian $3^{\text {rd }}$ order transgression of the Vienna Basin, resulting in flooding of the Mistelbach and Reinthal canyons (Fig. 6c). However, this transgressive event is minor compared to the middle Badenian Ba2-TST2 transgressive systems tract, culminating in the Badenian maximum flooding surface Ba2-mfs2 (Fig. 7c).

In addition to seismic and well data, outcrops are available for this systems tract. Shoreline deposits of the Ba2TST2 are exposed on the footwall of the Steinberg Fault (Schnabel et al., 2002) and along the Leitha Mountains in the southern part of the Vienna Basin (Strauss et al., 2006; see Fig. 2 for position). The middle Badenian transgression causes major retrogradational backstepping of the shoreline towards the west (outside the area of investigation). The regional distribution of the Ba2-mfs2 is shown in Fig. 7c. Due to massive backstepping of the shoreline, siliciclastic sediment influx in the area of the Vienna Basin is limited. Therefore well logs indicate shale bearing successions with high gamma ray or spontaneous potential values in the entire basin (e.g. Fig. 13, Ba2-TST2). In addition, the combination of condensed shale sections with underlying sand-rich lowstand systems creates strong impedance contrasts (see high positive impedance amplitudes at approximately $1000 \mathrm{~m}$ depth in Fig. 12a). Moreover, low energy shallow marine environments allow growth of corallinacean shoals, detectable by strong negative impedance amplitudes in seismic maps (Fig. 14a). So, merging well and seismic data together, a coherent surface (Ba2-mfs2) can be traced in the entire Vienna Basin, subdividing the basin in a chronological older (lower to middle Badenian) and younger (middle to upper Badenian) succession (Fig. 4).

Additional to its importance as a stratigraphic key horizon, the Ba2-TST2 is critical with respect to overpressure, which constitutes a major drilling hazard in the Zistersdorf Depression and the Mühlberg High. The overpressure is probably caused by disequilibrium compaction, a process where high subsidence rates hinder expulsion of water from thick, shale-rich intervals. High tectonic subsidence rates of 700 to $1000 \mathrm{~m} /$ Ma have been determined for the relevant time interval (14.5-14.2 Ma) by Hölzel et al. (2008) and support this interpretation. The overpressure of the shale bearing interval increases with depth. Mud weight gradients (in specific gravity; SG) are used as an estimate for the formation pressure and increase from 1.33 SG at 2000 m depth (well MUE T010; Mühlberg High) to $1.7 \mathrm{SG}$ at $3500 \mathrm{~m}$ depth (well PALT T1; northern flank of the Zistersdorf Depression). For comparison, hydrostatic, non-overpressure intervals in the Badenian succession are typically drilled with mud weight $<1.1$ SG.

\subsection{Badenian syndepositional tectonics}

Mapping depositional environments across major fault zones (e.g. Steinberg Fault) allows assessing the role of strike-slip faulting during basin evolution. In fact, only alluvial environments in the early Badenian Mistelbach Canyon show a lateral displacement of about $2 \mathrm{~km}$ (Fig. 6a). In contrast, late Badenian to early Sarmatian incised valleys superpositioned on the Reinthal Canyon show only minor strike slip displacement along the Steinberg Fault. The maximum lateral offset between the thalweg of the valley on the footwall and the hanging wall from late Badenian to recent is about $300 \mathrm{~m}$.

This suggests that strike-slip faulting plays a role only during early Badenian basin evolution. Thereafter, accommodation and sediment fillings of the Vienna Basin are mainly controlled by extensional faulting, reflecting the change from a compressional to an extensional fault system, described by Decker (1996). Hence, the 
presumption that the Vienna Basin represents a classic pull-apart basin (Royden, 1988) should be re-considered. Lateral strike slip components may exist east or southeast of the area of investigation.

\section{Conclusions}

Based on a sequence stratigraphic model for the Badenian succession, eleven paleogeographic maps for the central and northern parts of the Austrian Vienna Basin have been created (Figs. 6-9). They represent all systems tracts of the Badenian succession and indicate the high temporal variability of depositional systems. Major outcomes of the study include:

- The sequence stratigraphic framework for the Badenian succession in the southern part of the Austrian Vienna Basin is applicable in its central and northern parts. In addition to the $3^{\text {rd }}$ order Ba1LST1 stratigraphic sequences, defined by Strauss et al. (2006), the Ba1-LST1 sequence is sub grouped into an early subaerial and late marine lowstand systems tract.

- The early Ba1-LST1 lowstand systems tract represents a depositional system of braided river systems in the Vienna Basin (incl. Aderklaa Conglomerate). This system is connected by a drainage system through the Waschberg Zone (Reinthal Canyon, Mistelbach Canyon) with the marine environment in the North Alpine-Carpathian Foredeep (Ivan Canyon; Fig. 6a).

- Extensional tectonic activity causes a major change in depositional systems between the early Ba1-LST1 and the late Ba1-LST1. Newly created accommodation in the Vienna Basin changes the prevailing sediment transport directions from northwest (Fig. 6a) to east (Fig. 6b). Thus, the late Ba1-LST1 sequence represents the oldest deposits of the paleo-Danube in the Vienna Basin.

- The paleo-Danube splits into two branches and used the Mistelbach and Reinthal canyons as entry points into the Vienna Basin, feeding the southern Zistersdorf and the northern Mühlberg deltas, respectively. Depending on tectonic subsidence, either the southern or the northern branch is more active.

- Sediment architecture of the lower and middle Badenian succession is strongly controlled by pre-Badenian topography (e.g. canyon systems, Spannberg Ridge).

- The middle Badenian Ba2-TST2 transgressive systems tract represents the most extensive flooding of the Vienna Basin. Due to massive backstepping of the shoreline, siliciclastic sediment influx in the Vienna Basin is limited, resulting in accumulation of shale-rich successions and allowing the growth of corallinacean shoals. Because of disequilibrium compaction, the shale-rich Ba2-TST2 is overpressured in the Zistersdorf Depression and the Mühlberg High.
- During the late Ba2-HST2, drowning of the Spannberg Ridge initiates a clockwise rotation of the Zistersdorf Delta. Thus, the Zistersdorf Delta is transformed into the Matzen Delta covering the Spannberg Ridge and filling accommodation south of the Spannberg Ridge (Figs. 8b, 9b).

- $\quad$ During Ba3-TST3/HST3, the Matzen and Mühlberg deltas merge. Sediment transport from the hinterland is mainly along to the southern branch of the paleo-Danube. Thus the Matzen Delta becomes the dominant delta system in the Austrian Vienna Basin.

- Mapping depositional systems across the Steinberg Fault shows that strike-slip faulting plays a (minor) role only during early Badenian basin evolution.

\section{Acknowledgements}

We appreciate the support by OMV providing a merged 3D seismic survey of the area of the study area, well log and well core data of more than 350 wells. Critical reviews by W. Piller and M. Schreilechner helped to improve the paper significantly.

\section{References}

Arzmüller, G., Buchta, S.B., Ralbovsky, E., Wessely, G., 2006. The Vienna Basin. In: Golonka, J., Picha, F.J. (eds), The Carpathians and their foreland: Geology and hydrocarbon resources. AAPG Memoir, 84, pp. 191-204. https:// doi.org/10.1306/M84985

Beidinger, A., Decker, K., 2016. Paleogene and Neogene kinematics of the Alpine-Carpathian fold-thrust belt at the Alpine-Carpathian transition. Tectonophysics, 690, 263-287. https://doi.org/10.1016/j.tecto.2016.09.002

Boote, D.R.D., Sachsenhofer, R.F, Tari, G., Arbouille, D., 2018. Petroleum provinces of the Paratethyan region. Journal of Petroleum Geology, 41/3, 247-297. https:// doi.org/10.1111/jpg.12703

Catuneanu, O., Abreu, V., Bhattacharya, , J.P., Blum, M.D., Dalrymple, R.W., Eriksson, P.G., Fielding, C.R., Fisher, W.L., Galloway, W.E., Gibling, M.R., Giles, K.A., Holbrook, J.M., Jordan, R., Kendall, C.G.St.C., Macurda, B., , Martinsen, O.J., Miall, A.D., Neal, J.E., Nummedal, D., Pomar, L., Posamentier, H.W., Pratt, B.R., Sarg, J.F., Shanley, K.W., Steel, R.J., Strasser, A., Tucker, M.E., Winker, C., 2009. Towards the standardization of sequence stratigraphy. Elsevier, Earth-Science Review, 92, 1-33.

Catuneanu, O., Galloway, W.E., Kendall, C.G.St.C., Miall, A.D., Posamentier, H.W., Strasser, A., Tucker, M.E., 2011. Sequence stratigraphy: methodology and nomenclature. Newsletter on Stratigraphy, 44/3, 173-245. https:// doi.org/10.1127/0078-0421/2011/0011

Catuneanu, O., 2017. Sequence Stratigraphy: Guidelines for a Standard Methodology. Elsevier, Stratigraphy and Timescales, 2, 1-57. https://doi.org/10.1016/bs. sats.2017.07.003

Decker, K., 1996. Miocene tectonics at the Alpine-Carpathian junction and the evolution of the Vienna Basin. Mitteilungen der Gesellschaft der Geologie und Bergbaustudenten Österreichs, 41, 33-44. 
Dellmour, R., Harzhauser, M., 2012. The Iváň Canyon, a large Miocene canyon in the Alpine-Carpathian Foredeep. Marine and Petroleum Geology, 38, 83-94. https:// doi.org/10.1016/j.marpetgeo.2012.07.001

Ebner, F., Sachsenhofer, R.F., 1995. Paleogeography, subsidence and thermal history of the Neogene Styrian Basin (Pannonian basin system, Austria). Tectonophysics, 242, 133-150.

Emery, D., Myers, K.J., 1996. Sequence stratigraphy: Oxford, Blackwell Science, 297 pp. https://doi.org/10.1017/ S0016756897307389

Fuchs, R., Hamilton, W., 2006. New depositional architecture for an old Giant: the Matzen field, Austria. In: Golonka, J., Picha, F.J. (eds), The Carpathians and their foreland: Geology and hydrocarbon resources, AAPG Memoir, 84, 205-219. https://doi.org/10.1306/985609m843069

Grill, R., 1941. Stratigraphische Untersuchungen mit Hilfe von Mikrofaunen im Wiener Becken und den benachbarten Molasse-Anteilen. Öl und Kohle, 37, 595-602.

Grill, R., 1943. Über mikropaläontologische Gliederungsmöglichkeiten im Miozän des Wiener Beckens. Mitteilungen der Reichsanstalt für Bodenforschung, 6, 33-44.

Grunert, P., Hinsch, R., Sachsenhofer, R.F., Bechtel, A., Ćorić, S., Harzhauser, M., Piller, W.E., Sperl, H., 2013. Early Burdigalian infill of the Puchkirchner through (North Alpine Foreland basin, Central Paratethys): Facies development and sequence stratigraphy. Marine and Petroleum Geology, 39, 164-186. https://doi.org/10.1016/j. marpetgeo.2012.08.009

Hamilton, W., Wagner, L., Wessely, G., 2000. Oil and gas in Austria. Mitteilungen der Österreichischen Geologischen Gesellschaft, 92, 235262.

Haq, B.U., Hardenbol, J., Vail, P.R., 1988. Mesozoic and Cenozoic chronostratigraphy and cycles of sea-level changes. In: Wilgus, C.K. (ed.), Sea-level changes - an integrated approach. SEPM Special Publications, 42, 71-108. https://doi.org/10.2110/pec.88.01.0071

Hardenbol, J., Thierry, J., Farley, M.B., Jacquin, T., Graciansky, P.C., Vail, P.R., 1998. Mesozoic and Cenozoic Sequence Chronostratigraphic Framework of European Basins. In: Graciansky, P.C., Hardenbol, J., Jacquin, T., Vail, P.R. (eds), Mesozoic and Cenozoic Sequence Stratigraphy of European Basins. SEPM Special Publications, 60, pp. 3-13. https://doi.org/10.2110/pec.98.02.0003

Harzhauser, M., Theobalt, D., Strauss, P., Mandic, O., Carnevale, G., Piller, W.E., 2017. Miocene biostratigraphy and paleoecology of the Mistelbach Halfgraben in the northwestern Vienna Basin (Lower Austria). Jahrbuch der Geologischen Bundesanstalt, 157, 57-108.

Harzhauser, M., Grunert, P., Mandic, O., Lukeneder, P., García Gallardo, Á., Neubauer, T.A., Carnevale, G., Landau, B.M., Sauer, R., Strauss, P., 2018. Middle and Late Badenian palaeoenvironments in the northern Vienna Basin and their potential link to the Badenian Salinity Crisis. Geologica Carpathica, 69, 129-168. https://doi. org/10.1515/geoca-2018-0009.

Harzhauser, M., Theobalt, D., Strauss, P., Mandic, O., Piller, W.E., 2019. Seismic-based lower and middle Miocene stratigraphy in the northwestern Vienna Basin (Austria). Newsletter on Stratigraphy, 52, 221-247. https://doi. org/10.1127/nos/2018/0490

Hilgen, F.J., Lourens, L.J., Van Dam, J.A. with contributions by Beu, A.G., Boyes, A.F., Cooper, R.A., Krijgsman, W., Ogg, J.G., Piller, W.E.,, Wilson, D.S., 2012. The Neogene Period. In: Gradstein, F.M., Ogg, J.G., Schmitz, M.D., Ogg, G.M. (eds), The Geologic Time Scale 2012. Elsevier, Amsterdam, pp. 923-978.

Hinsch, R., Decker, K., Peresson, H, 2005. 3D seismic interpretation and structural modeling in the Vienna Basin: implication for Miocene to recent kinematics, Austrian Journal of Earth Science, 97, 38-50.

Hölzel, M., Wagreich, M., Faber, R., Strauss, P., 2008. Regional subsidence analysis in the Vienna Basin (Austria). Austrian Journal of Earth Science, 101, 88-98.

Jiříček R., Seifert, P., 1990. Paleogeograpy of the Neogene in the Vienna Basin and the adjacent part of the foredeep, In: Minarikova, D., Lobitzer, H. (eds), 30 years of geological cooperation between Austria and Czechoslovakia, Praque, 89-105.

Knox, P.R., Fouad, K., Zinke, S., Light, M., Skolnakorn, J., Shi, S., Von Lunen, E., Yeh, J.S., Finley, R.J., Barba, R.E., Jr., Holtz, M.H., Mercer, M., Handford, R., Martinez, C., Sipahioglu, O., Rassi, C., Hamilton, D.S., Akhter, M.S., Clift, S.J., Dunlap, D.B., Mahoney, M., Treviño, R.H., Bullen, G., Chang, C.Y., Ramberger, R., Fuchs, R., Gstrein, M., Zier, N., Baltas, P., Jarnik, M., 2000. Optimizing hydrocarbon recovery from the Matzen Field, Vienna Basin, Austria: The University of Texas at Austin, Bureau of Economic Geology, final report prepared for OMV, under agreement no. UTA98-0377, variously paginated.

Kollmann, K., 1965. Jungtertiär im Steirischen Becken. Mitteilungen der Geologischen Gesellschaft in Wien, 57, 479-632.

Kováč, M., Baráth, I., Harzhauser, M., Hlavatý, I., Hudáčková, N., 2004. Miocene depositional systems and sequence stratigraphy of the Vienna Basin. Courier des Forschungs-Instituts Senckenberg, 246, 187-212.

Kováč, M., Andreyeva-Grogorovich, A., Bajraktarević, Z Brzobohatý, R., Filipescu, S., Fodor, L., Harzhauser, M., Nagymarosy, A., Oszczoko, N., Pavelic, D., Rögl, F., Saftic, B., Sliva, U., Studencka, B., 2007. Badenian evolution of the Central Paratethys Sea: paleogeography, climate and eustatic sea-level changes, Geologica Carpathica, 58, 579-606.

Kreutzer, N., 1986. Die Ablagerungssequenzen der miozänen Badener Serie im Feld Matzen und im zentralen Wiener Becken. Erdöl-Erdgas-Kohle, 102, 492502.

Kreutzer, N., 1992. Matzen Field, Austria (Vienna Basin). AAPG treatise of petroleum geology. Atlas of Oil and Gas Fields, Structural Traps, 7, 57-93.

Kreutzer, N., 1993. Das Neogen des Wiener Beckens. In: Brix, F., Schultz, O. (eds), Erdöl und Erdgas in Österreich. (2. Auflage) Veröffentlichungen aus dem Naturhistorischen Museum, Neue Folge, 19, Naturhistorisches Museum Wien, 232-248. 
Kreutzer, N., Hlavay, V., 1990. Sediments of the Miocene (mainly Badenian) in the Matzen area in Austria and in the southern part of the Vienna Basin in Czechoslovakia (Remark: Southern part - CSFR part in the central part of the Vienna Basin). In: Minarikova, D., Lobitzer, H. (eds), Thirty years of geological cooperation between Austria and Czechoslovakia (Festival Volume). Federal Geological Survey Vienna and Geological Survey Prague, 112118.

Kuffner, T., Sauer, R., 2006. Core documentation, sedimentological and petrographical analysis of Zistersdorf 004. Unpublished OMV Report, Gänserndorf, 65 pp.

Kuffner, T., 2010. Facies, sequence stratigraphy and reservoir characterization of the 8. TH - Schönkirchen - Matzen area. Unpublished OMV internal report, Gänserndorf, 102 pp.

Kuffner, T., 2011. Facies and sequence stratigraphy of the 8. TH. Unpublished OMV internal report, Gänserndorf, $25 \mathrm{pp}$.

Kuffner, T., 2012. Facies and sequence stratigraphy of selected Badenian cores from the Vienna Basin. Unpublished OMV internal report, Gänserndorf, 83 pp.

Kuffner, T., 2016. Sequence stratigraphic correlation and facies model update - 8.TH-polymer pilot sector. Unpublished OMV internal report, Gänserndorf, 14 pp.

Kuffner, T., 2017. Facies analysis and sequence stratigraphic correlation of the 8.TH and 9.TH - Matzen area. Unpublished OMV internal report, Gänserndorf, 110 pp. Kuffner, T., 2017: Facies analysis of the 16. TH Matzen Sand - Bockfliess area (PU216-20). Unpublished OMV internal report, Gänserndorf, $63 \mathrm{pp}$.

Latal, C., Piller, W.E., 2003. Stable Isotope Signatures at the Karpatian/Badenian Boundary in the Styrian Basin. In: Brzobohatý, R., Cicha, I., Kovác, M., Rögl, F. (eds), The Karpatian - a Lower Miocene stage of the Central Paratethys, 27-34. Brno: Masaryk University.

Meulenkamp, J.E., Kováč, M., Cicha, I., 1996. On Late Oligocene to Pliocene depocentre migrations and the evolution of the Carpathian-Pannonian system. Tectonophysics, 266, 301-317. https://doi.org/10.1016/ S0040-1951(96)00195-3

Picha, F.J., Stranok, Z., Krejci, O., 2006. Geology and hydrocarbons resources of the West Carpathians and their foreland, Czech Republic. In: Golonka, J., Picha, F.J. (eds), The Carpathians and their foreland: Geology and hydrocarbon resources, AAPG Memoir, 84, 49-175. https:// doi.org/10.1306/985607M843067

Piller, W.E., Harzhauser, M., Mandic, O., 2007. Miocene Central Paratethys stratigraphy - current status and future directions. Stratigraphy, 4, 151-168.

Posamentier, H.W., Vail, P.R., 1988. Eustatic controls on clastic deposition. II. Sequence and systems tract models. In: Wilgus, C.K., Hastings, B.S., Kendall, C.G.St.C., Posamentier, H.W., Ross, C.A., Van Wagoner, J.C. (eds), Sea-level Changes - An Integrated Approach, SEPM Special Publication, 42, 125-154.

Ratschbacher, L., Frisch, W., Linzer, H.G., Merle, O., 1991a. Lateral extrusion in the eastern Alps, part II: structural analysis. Tectonics, 10, 257-271. https://doi. org/10.1029/90TC02623

Ratschbacher, L., Merle, O., Davy, P., Cobbold, P., 1991 b. Lateral extrusion in the eastern Alps, part I: boundary conditions and experiments scaled for gravity. Tectonics, 10, 245-256. https://doi.org/10.1029/90TC02622

Royden, L.H., 1985. The Vienna Basin: a thin-skinned pullapart basin. In: Biddle, K., Christie-Blick, N. (eds), Strike Slip Deformation, Basin Formation and Sedimentation. Society of Economics Palaeontologists and Mineralogists Special Publication, 37, pp. 319-338. https://doi. org/10.2110/pec.85.37.0319

Royden, L.H., 1988. Late Cenozoic tectonics of the Pannonian basin system. In: Royden, L.H., Horvath, F. (eds), The Pannonian Basin - A Study in Basin Evolution. AAPG Memoir, 45, pp. 27-48. https://doi.org/10.1306/ M45474C3

Rögl, F., Spezzaferri, S., Ćorić, S., 2002. Micropaleontology and biostratigraphy of the Karpatian-Badenian transition (Early-Middle Miocene boundary) in Austria (Central Paratethys). Courier Forschungsinstitut Senckenberg, 237, 47-67.

Rögl, F., Ćorić, S., Hohenegger, J., Pervesler, P., Roetzel, R., Scholger, R., Spezzaferri, S., Stingl, K., 2007. The Styrian Tectonic Phase - A series of events at the Early/Middle Miocene boundary revised and stratified (Styrian Basin, Central Paratethys). Joannea Geol. Paläont., 89-91.

Rupprecht, B.J., Sachsenhofer, R.F., Zach, C., Bechtel, A., Gratzer, R., Kucher, F., 2019. Oil and Gas in the Vienna Basin: hydrocarbon generation and alteration in a classical hydrocarbon province. Petroleum Geoscience, 25, 3-29. Salcher, B.C., Meurers, J., Smit, J., Decker, K., Hölzel, M., Wagreich, M., 2012. Strike-slip tectonics and Quaternary basin formation along the Vienna Basin fault system inferred from Bouguer gravity derivatives. Tectonics, 31, 3 pp. https://doi.org/10.1029/2011TC002979

Sauer, R., Seifert, P., Wessely, G., (eds.) 1992. Guidebook to excursion in the Vienna Basin and the adjacent Alpine Carpathian thrustbelt in Austria. Mitteilungen der Geologischen Gesellschaft, 85, 264 pp.

Schnabel, W., Krenmayr, H.-G., Mandl, G.W., Nowotny, A., Roetzel, R., Scharbert, S., (eds) 2002. Legende und kurze Erläuterungen zur geologischen Karte von Niederösterreich 1:200.000. Geologische Bundesanstalt Wien.

Strauss, P., Harzhauser, M., Hinsch, R., Wagreich, M., 2006. Sequence stratigraphy in a classic pull-apart basin (Neogene, Vienna Basin). A 3D seismic based integrated approach. Geologica Carpathica, 57, 185-197.

Stille, H., 1924. Grundfragen vergleichender Tektonik. Borntraeger, Berlin, 443 pp.

Wagreich, M., Schmid, H.P., 2002. Backstripping dip-slip fault histories: apparent slip rates for the Miocene of the Vienna Basin. Terra Nova, 14, 163-168. https://doi.org/ 10.1046/j.1365-3121.2002.00404.

Van Wagoner, J.C., Mitchum, R.M., Campion, K.M., Rahmanian, V.D., 1990. Siliciclastic Sequence stratigraphy in Well Logs, Cores and Outcrops: Concepts for 
High-Resolution Correlation of Time and Facies: AAPG Methods in Exploration Series, 7.

Weissenbäck, M., 1996. Lower to middle Miocene sedimentation model of the central Vienna Basin. In: Wessely, G., Liebl W. (eds), Oil and Gas in Alpidic Thrustbelts and Basins of Central and Eastern Europe. EAGE Special Publications, $5,255-363$.
Wessely, G., 2006. Niederösterreich. Geologie der Österreichischen Bundesländer. Geologische Bundesanstalt Wien, 416 pp.

Received: 18.12 .2019

Accepted: 28.05.2020

Editorial handling: Björn Berning 